\title{
From gut microbiota to host appetite: gut microbiota-derived metabolites as key regulators
}

\author{
Hui Han ${ }^{1,2 \dagger} \mathbb{D}$, Bao $\mathrm{Yi}^{1 \dagger}$, Ruqing Zhong ${ }^{1}$, Mengyu Wang ${ }^{1}$, Shunfen Zhang ${ }^{1}$, Jie Ma ${ }^{3}$, Yulong Yin ${ }^{3,4}$, Jie Yin ${ }^{3 *}$, \\ Liang Chen ${ }^{1 *}$ and Hongfu Zhang ${ }^{1,3^{*}}$
}

\begin{abstract}
Feelings of hunger and satiety are the key determinants for maintaining the life of humans and animals. Disturbed appetite control may disrupt the metabolic health of the host and cause various metabolic disorders. A variety of factors have been implicated in appetite control, including gut microbiota, which develop the intricate interactions to manipulate the metabolic requirements and hedonic feelings. Gut microbial metabolites and components act as appetite-related signaling molecules to regulate appetite-related hormone secretion and the immune system, or act directly on hypothalamic neurons. Herein, we summarize the effects of gut microbiota on host appetite and consider the potential molecular mechanisms. Furthermore, we propose that the manipulation of gut microbiota represents a clinical therapeutic potential for lessening the development and consequence of appetite-related disorders.
\end{abstract}

Keywords: Gut microbiota, Appetite, Metabolites, Hormone, Immune

\section{Introduction}

Feelings of hunger and satiety are principal involuntary motivations for feeding behavior in humans and animals [1-4]. Appetite, governed by the central nervous system (CNS), corresponds to a short-term signal from gastrointestinal hormones to control food intake and a long-term signal from adipose tissue associated with energy stores and environmental cues [5]. The CNS, hormones, and vagal afferents develop an intricate appetite system to initiate or inhibit food intake, while lack of physiological control of appetite generally results in eating disorders, such as anorexia

\footnotetext{
*Correspondence: yinjie2014@126.com; chenliang01@caas.cn;

zhanghongfu@caas.cn

${ }^{\dagger} \mathrm{Hui}$ Han and Bao Yi contributed equally to this work.

${ }^{3}$ College of Animal Science and Technology, Hunan Agricultural University, Changsha 410128, China

${ }^{1}$ State Key Laboratory of Animal Nutrition, Institute of Animal Science, Chinese Academy of Agricultural Sciences, Beijing 100193, China Full list of author information is available at the end of the article
}

nervosa (AN) and bulimia nervosa (BN), as well as metabolic diseases, such as obesity, which are potential threats to human host health [6-9].

Gastrointestinal tract is home to microbiota, which mutually interact with the host to modulate gut physiology and extraintestinal functions. Energy metabolism serves as a key point for microbiota and host interaction, as the gut microbiota not only receive energy from the host to maintain normal growth, but also supply the host with energy by releasing enzymes and metabolites, such as short-chain fatty acids (SCFAs), amino acids, bile acids (BAs), caseinolytic proteasB (ClpB), and lipopolysaccharide (LPS) [10]. To date, numerous studies are supporting the notion that gut microbiomes exert a profound influence on eating behavior in humans and animals [11-17]. Firstly, eating disorders are accompanied with alterations of gut microbiota. For example, AN patients have lower fecal microbial $\alpha$-diversity and different fecal bacterial compositions [11, 18-20], while BN 
patients are characterized by a higher abundance of bacterial ClpB protein [21]. Secondly, gut microbial alterations further affect appetite and feeding behavior evidenced by a piglet model that lysine restrictionshaped microbial communities are associated with decreased circulating satiety hormones and increased feed intake [22]. Together, the gut microbiota and appetite system are highly associated and energy metabolism and microbial metabolites may serve as the potential mechanisms. Indeed, a review in 2017 has expertly summarized the integrative homeostatic model of appetite control related to the gut microbial metabolites mediated by bacterial growth cycle [10]. Diet interventions may dominate over host genetics to influence the incidence and development of metabolic diseases [23, 24], which is, at least in part, due to the modulations of gut microbial communities and metabolism. Thus, understanding the effects of nutrient-altered microbial metabolites on host metabolism and the potential molecular mechanisms provide an opportunity for the application of dietary interventions in metabolic diseases.

In this review, we further discuss the most recent insights regarding how the gut microbiota and its metabolites that are implicated in food consumption may link to appetite-related hormonal and neural signals. Microbiota-derived metabolites and components are focused on the appetite regulation via modulating hormone secretion and immune system function (Figs. 1 and 2). van de Wouw et al. have reviewed mechanistic insights into the pathway of how gut microbial metabolite, including GABA, BAs, and SCFAs, may contribute to host metabolism and appetite [25]. Notably, microbial metabolites related to appetite control are not limited to these. We herein evaluate a series of recently discovered gut microbial metabolites, such as succinate, branchedchain amino acids (BCAAs), and bacterial proteins, and their potential role as messengers between the gut microbiota and host energy homeostasis in appetite

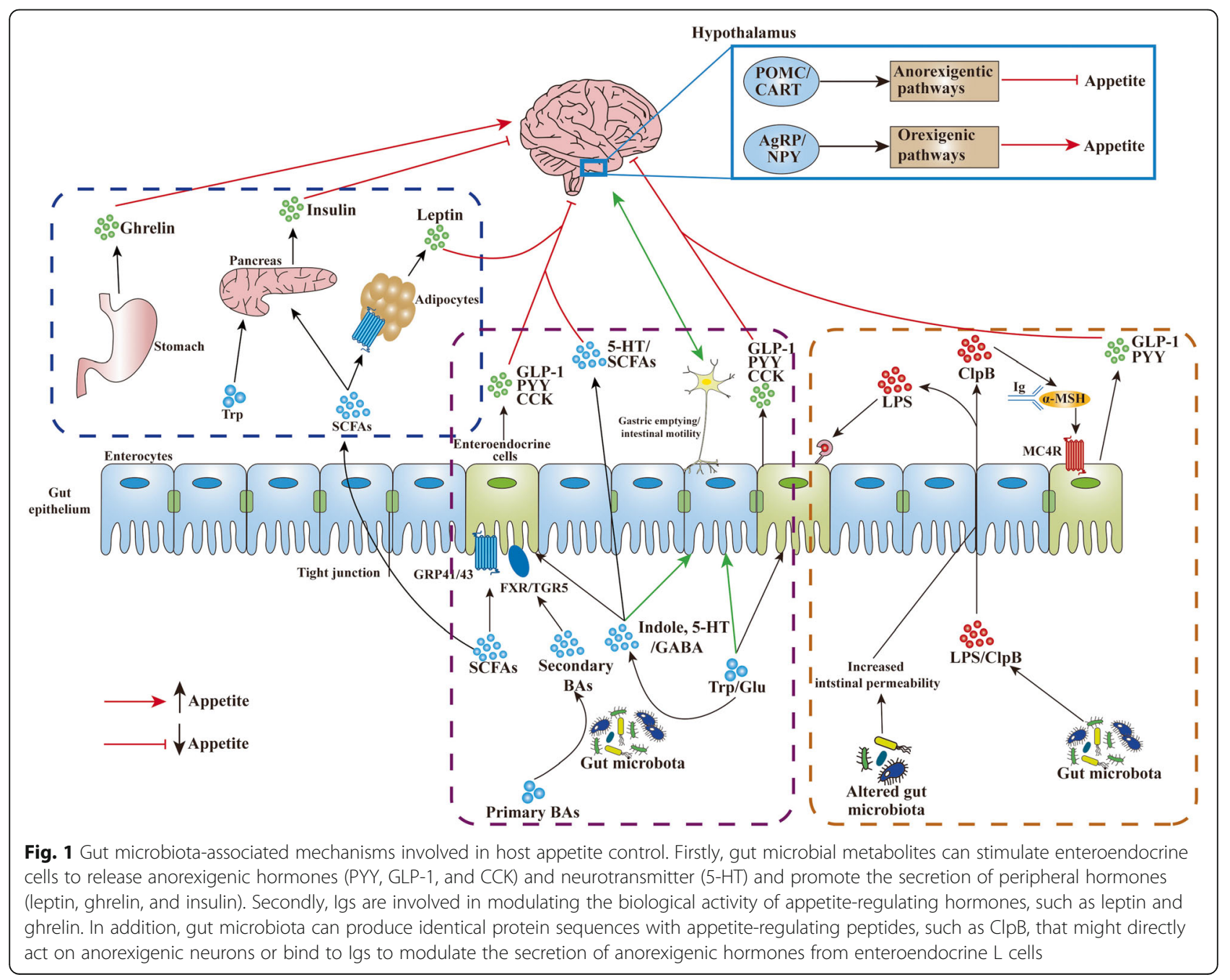




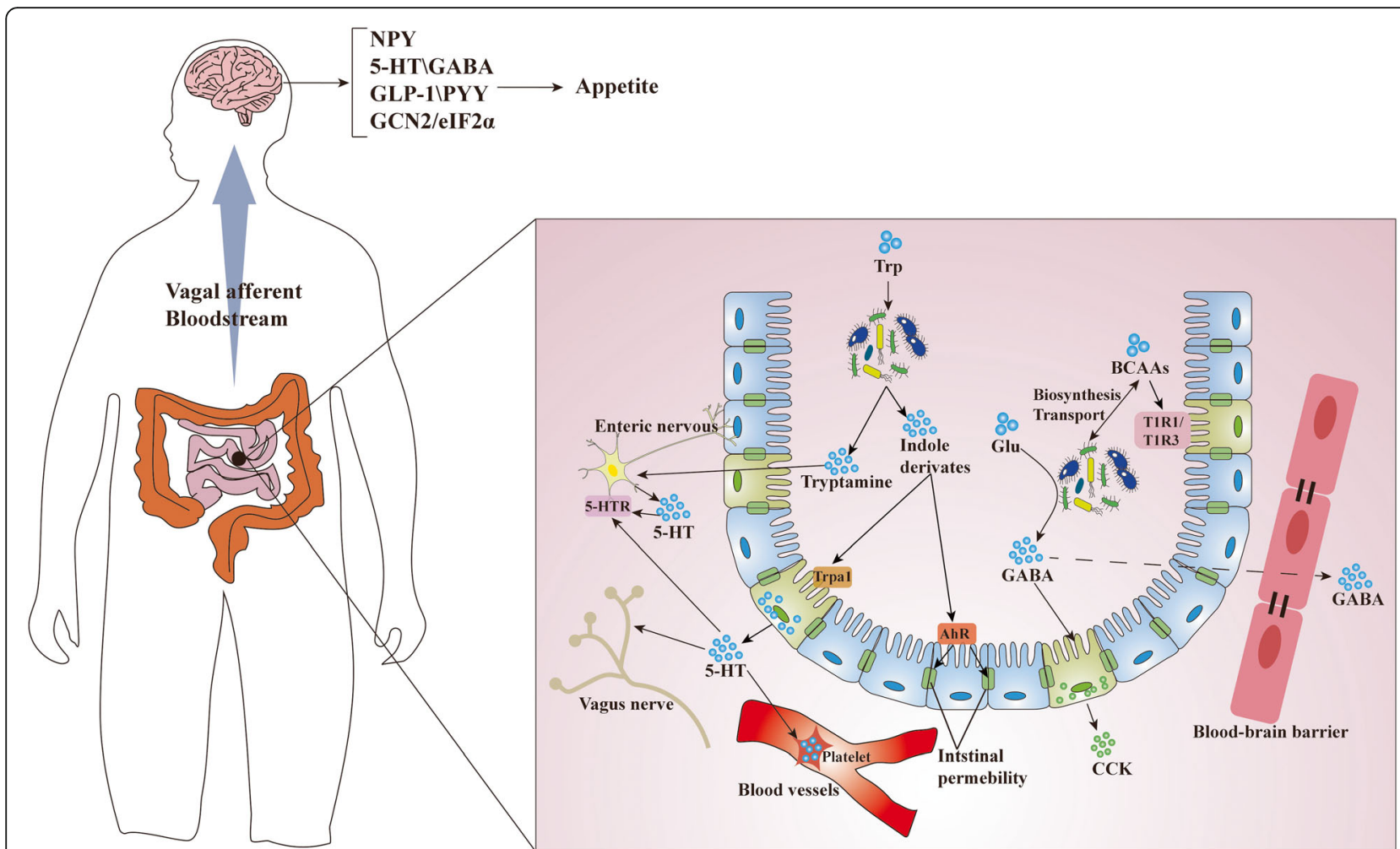

Fig. 2 Gut microbial metabolites derived from amino acids influence host appetite control. Microbiota-derived amino acids mediate a variety of effects on appetite control. (1) Trp can be metabolized by commensal bacteria to produce tryptamine that affect the production and secretion of 5-HT, and some indole derivatives that are associated with maintaining intestinal permeability. 5-HT can act as neurotransmitter that conveys signals from the gut to the brain and mediate appetite control. (2) Glu can be metabolized by gut microbiota to produce GABA, which is considered a neurotransmitter to regulate the secretion of appetite-related hormones and intestinal motility. (3) Gut microbiota are involved in the biosynthesis and transport of BCAAs. The imbalance of BCAAs: non-BCAAs ratio can influence the 5-HT production in the hypothalamus. In addition, BCAAs can control appetite through mediating intestinal amino acid receptors and hypothalamic NCG2/elF2a signaling. The sensory, hormonal, and neural signals are sent to the brain through vagal afferents or bloodstream to regulate appetite

control. Based on the importance of organic acids, amino acids, and fatty acids related to gut microbiota metabolism, we also provide insights for microbiometargeted therapies to treat or prevent appetite-related disorders (Fig. 3).

\section{Gut microbiota and appetite-related hormones}

The physiological control of appetite is mediated by circulating orexigenic and anorexigenic hormones (e.g., leptin, insulin, and ghrelin) produced by peripheral organs, including gut, adipose tissue, and pancreas. Here, we summarize the impacts of specific changes in the microbial compositions on appetite-related hormones, which play a key role in modulating brain behavior and function through the humoral or the neural pathway.

\section{Leptin}

Leptin, secreted mostly from the white adipose tissues, reflects the body's energy stores [26, 27]. The stomach and intestine are also sources of leptin and contain leptin receptors $[28,29]$. Leptin can cross the blood-brain barrier $(\mathrm{BBB})$ and then activates leptin receptors on the two subsets of neurons in the hypothalamic arcuate nucleus (ARC). Specifically, leptin can activate the anorexigenic neurons expressing proopiomelanocortin (POMC) and inhibit orexigenic neurons expressing neuropeptide tyrosine (NPY) and agouti-related protein (AgRP), which collectively inhibit host appetite [30-34].

Evidence from rodent experiments suggests that gut microbial abundance and richness are related to the leptin signaling. For example, in human with and without obesity, lower bacterial richness is associated with higher circulating leptin concentrations [35]. In addition, in vivo and in vitro studies showed that the translocation of living gut microbiota to adipose tissues induced by increased intestinal permeability influences energy metabolism through inhibiting the leptin signaling in obese humans and mice [36, 37]. Leptin treatment decreases the hypothalamic NPY and AgRP expression in germ free (GF) mice, whereas has no effect in WT mice [38], suggesting an important role of gut microbiota in leptin signaling. Furthermore, the depletion of gut microbiota 


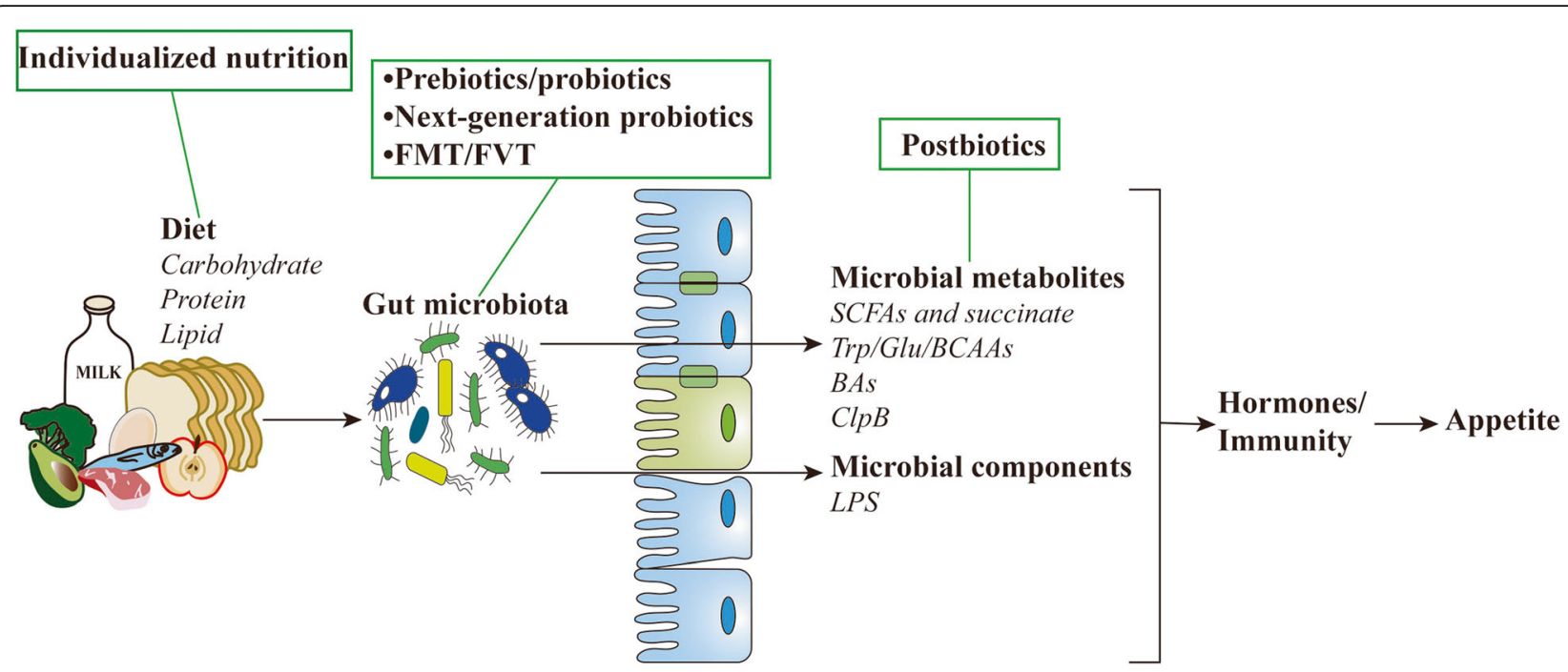

Fig. 3 Potential clinical applications related to gut microbiota in appetite-related disorders. Gut microbial composition and metabolites contribute appetite control through altering the production and secretion of appetite-related hormones and influencing the immune system. Modulation of gut microbial composition is feasible via various strategies, including dietary interventions, probiotics, prebiotics, next-generation probiotics, FMT, and FVT. In addition, postbiotics can specifically and precisely change the microbial metabolites

inhibits leptin signaling and food intake in mice fed with the normal diet, whereas inhibits food intake but without affecting leptin signaling in mice fed with the highfat diet $[39,40]$, demonstrating that the effect of gut microbiota on leptin signaling is dependent on the diet. Interestingly, probiotics or prebiotics supplementation has different and even contrary effects on the leptin signaling and food intake in genetically and diet-induced obese mice [41-44]. These conflicting results may be because the functional consequences of the microbial taxa shift have inconsistent outcomes to the leptin signaling [41], and the precise outcomes of specific microbiota need further investigations. Furthermore, whether the prebiotics and probiotics have comparable influence in animals and humans with eating disorders is still unclear.

\section{Ghrelin}

Contrary to leptin, ghrelin is mainly a stomach-derived hunger hormone that acts as a ligand for the growth hormone secretagogue receptor (GSHR). In addition to the stomach, the fetal islets and adults' duodenum also synthesize and secret ghrelin, but the quantity appears to be small $[45,46]$. Ghrelin can transmit starvation signals to the brain via binding to its receptor on vagal afferent neurons [47]. Ghrelin is also able to cross the $\mathrm{BBB}$ and directly activate AgRP/NPY and inhibit POMC neurons through binding to GSHR in the brain, which will lead to increased food intake and decreased energy expenditure [48-51]. Furthermore, recent studies have shown that the gut microbiota are involved in regulating appetite through modulating ghrelin-related signaling pathways [52, 53]. For example, administration of prebiotics, such as inulin and oligofructose, inhibits feed intake via enhancing the synthesis of glucagon-like peptide (GLP-1) and peptide YY (PYY), as well as inhibiting the ghrelin production in obese and healthy adults $[54,55]$. However, another intervention study with oligofructoseenriched inulin for 16 weeks in obese children decreased food intake and enhanced blood fasting ghrelin concentration, while has no significant effects on the GLP-1 and PYY, and insulin concentration [56]. The investigators suspected that increased ghrelin may act as a defense against diet-inhibited caloric intake. These conflicting experimental results call for studies in which the ghrelin signal and appetite are tested after prebiotics or probiotics interventions to explore the potentially dietary strategies for abnormal eating behavior treatment. In addition to metabolic needs, the hedonic effects of food can also induce food intake in individuals, which may be because eating food can make them feel better and relieve stress [57]. Studies have demonstrated that leptin and ghrelin are responsible for both homeostatic and hedonic aspects of feeding by regulating dopamine signaling [57-60]. Overall, these results show that the gut microbiota may regulate feed intake by regulating leptinrelated signaling pathways.

\section{Insulin}

In addition to controlling glucose and energy homeostasis, insulin can function as a satiety signal [61]. Various studies have shown that insulin-related signaling pathways are associated with decreased food intake in insects, mice, and humans [62, 63]. Similar to leptin and 
ghrelin, insulin can also cross the BBB and control appetite by acting on the POMC/CART and NPY/AgRP neurons after binding with its receptor [38, 62]. In addition, insulin and leptin treatment decrease food intake by increasing the expression of angiopoietin-like protein 14 (Angpt14) and inhibiting hypothalamic AMPK signaling in mice [64]. As demonstrated in humans and mice, insulin signaling is influenced by the gut microbial communities. For example, humans with low gut bacterial richness have higher insulin resistance [35], whereas mice with deficient and deleted gut microbiota have higher insulin sensitivity [65, 66]. Furthermore, altered gut microbiota induced by probiotics inhibits food intake by alleviating insulin resistance and inhibiting NPY expression in diet-induced obese mice [44, 67]. These observations suggest that the gut microbiota could participate in modulating appetite by influencing central insulin signal.

In summary, hormones derived from peripheral organs participate in various metabolism processes involved in appetite, such as energy homeostasis and hedonic feeding. It remains possible that altered gut microbiota may have an influence on host appetite through regulating the secretion of appetite-related hormones, pending confirmed evidence from more rigorous tests in clinical trials.

\section{Gut microbial metabolites and appetite}

It has long been suggested that gut microbial metabolites play a key role in generating energy and mediating microbiota-gut-brain communication, which may affect the physiological and psychological functions of mammals $[68,69]$. A better understanding of the interaction between gut microbial metabolites and appetite will help to design personalized nutritional strategies for treating eating disorders. We will hereafter update the molecular mechanisms, and we also reviewed some other microbial metabolites that are related to appetite control.

\section{SCFAs}

The SCFAs (i.e., acetate, propionate, and butyrate) are generated by the gut bacterial fermentation of lowdigestible polysaccharides, such as dietary fibers. In addition to providing energy, SCFAs widely act as signaling molecules and play a key role in appetite control. A piglet study observed both negative (Ruminococcaceae and Lactobacillus) and positive (Prevotella) relationships between the SCFAs and lactic acid-producing gut microbiota and feed intake [70]. SCFAs exhibit their metabolic and appetite-related functions by binding to the Gprotein-coupled receptors in various tissues and organs, including free fatty acid receptor 3 (FFAR3, GRP41) and free fatty acid receptor 2 (FFAR2, GRP43). Signaling via these receptors has contrary effects (reviewed in detail elsewhere [71]). On one hand, SCFAs can activate ghrelin-related signaling and inhibit the insulin secretion by activating free fatty acid receptor 3 (FFAR3, GRP41) in islets, but the effects of SCFAs on appetite through activating GRP41 are unclear [71-73]. On the other hand, SCFAs can inhibit appetite by binding to the free fatty acid receptor 2 (FFAR2, GRP43), which further activates the release of GLP-1, PYY, insulin, and leptin to signal to appetite system (Fig. 1) [74-77]. GLP-1 and PYY, two anorexigenic hormones [48, 78-82], can cross the $\mathrm{BBB}$ and act as direct brain neuropeptides to activate POMC [49, 83]. In addition, GLP-1 and PYY help to increase insulin sensitivity and slow gastric emptying and intestinal motility to affect appetite [84-87]. Intriguingly, acute colonic propionate delivery decreases food intake and stimulates the secretion of PYY and GLP-1, while long-term colonic propionate delivery has little effects on PYY and GLP-1 release in humans [74], which may be associated with propionate resistance. Besides, a clinical study indicated that the reward processing and hedonic response rather than the secretion of PYY and GLP-1 contribute to the inulin-propionate-caused energy intake reduction [88]. Furthermore, gut-derived SCFAs entering the bloodstream can also cross the BBB and directly affect appetite-related neurons in the brain [89]. For example, intraperitoneal injection of acetate significantly decreases food intake by increasing the expression of POMC and inhibiting agouti-related peptide (AgRP) in the hypothalamus, but without affecting the concentration of circulating PYY and GLP-1, suggesting that acetate may directly regulate appetite by generating an anorectic signal in the hypothalamic ARC [89]. Moreover, findings in human and animal studies suggested that increased intestinal permeability, partially induced by microbial alterations, is associated with the eating disorders [90-95], which may be due to the elevated circulating $\mathrm{ClpB}$ and LPS levels [96-99]. A recent study showed that the FMT-enhanced SCFA levels contribute to the decreased intestinal permeability and increased food intake in mice with neurological disability [100]. Taken together, these results suggest that gut-derived SCFAs are involved in appetite control through hormonal and central effects. However, different dietary fiber supplementation has different influence on host appetite and energy intake, which is due to the complex effects of different SCFAs on energy metabolism (reviewed in detail elsewhere [25, 101]). These conflicting results suggest that further mechanistic research is needed to investigate the influences of each SCFA or in combination on appetite control in order to precisely and systematically explore the relationship between SCFAs and appetite control. 


\section{Succinate}

Succinate is a common product produced by gut microbial carbohydrate fermentation, which was not noticed in van de Wouw and co-workers' review [25]. Evidence from human studies suggests that the microbiotaderived succinate contributes to the host energy homeostasis. The obese individuals display increased circulating succinate concentrations, which could be attributed to those with obesity produce more gut microbiota-derived succinate as compared with healthy individuals [102]. Meanwhile, in obese patients, dietary weight loss intervention alters gut microbiota and decreases circulating succinate concentration [102]. Nevertheless, the results from studies investigating the effects of succinate on appetite-related signaling are inconsistent. One series of studies suggested that succinate treatment improves glucose and insulin tolerance and elevates energy expenditure, but without affecting the food intake in mice fed with high-fat/high-sucrose and high-fat diet [103, 104]. Interestingly, another study demonstrated that supplementation with succinate reduces food intake and plasma insulin concentration in genetic obese $(o b / o b)$ mice [105], which might be due to the succinatepromoted intestinal gluconeogenesis that can be detected by the hepatoportal glucose sensor and then send an anorectic signal to the brain [106]. Overall, these outcomes derived from mice models indicated that succinate might be involved in appetite control. However, studies in humans that investigate the effects of succinate on appetite regulation are currently lacking.

\section{Tryptophan (Trp)}

The gut microbiota plays an important role in controlling the availability and metabolism of Trp, which directly or indirectly regulates metabolic homeostasis and even appetite [107-110]. Trp can both affect the gut hormone secretion and cross the BBB to directly activate satiety circuits in the brain [111]. Amounting studies have been performed to explore the effects of dietary supplementation and reduction of Trp on appetite control, whereas the results are inconsistent and contradictory. For example, animal studies showed that Trp administration can stimulate food intake by enhancing ghrelin, 5-HT, neuropeptide Y (NPY), and the pituitary growth hormone-insulin-like growth factor (GH-IGF) signaling [112, 113]. However, intragastric or intraduodenal Trp dose dependently inhibits appetite and promotes the production of CCK, GLP-1, and PYY in the healthy men, whereas failed to affect appetite in the obese men [114-116]. In line with this, an animal study also showed that the supplementation of $5 \% \operatorname{Trp}$ increases satiety and reduces feed intake in healthy rats [117]. Moreover, severe Trp restriction decreases the plasma leptin and ghrelin concentrations and increases the plasma GLP-1 and PYY concentrations, which leads to decreased feed intake and body weight, while moderate Trp restriction increases energy expenditure in obesity-prone rats [118]. These results suggest that the effects of Trp on appetite are complex and depend on the dosage of dietary Trp and the host metabolic conditions.

In terms of metabolites produced by the gut microbiota, indole can serve as a molecular signal to regulate food intake and appetite by stimulating GLP-1 secretion in enteroendocrine L cells [119-121]. A recent study found that the derivatives of indole, including indole-3ethanol (IEt), indole-3-pyruvate (IPyA), and indole-3aldehyde (I3A), also can decrease intestinal permeability by binding to their receptor, ary hydrocarbon receptor (AhR) [122], which may contribute to the intestinal barrier function and appetite control. Moreover, Trp is the precursor of $5-\mathrm{HT}$ and dominates the synthesis rate of intestinal and central 5-HT [108, 123, 124]. Studies using GF mice, gnotobiotic mice recolonized with sporeforming microbiota from SPF mice, and healthy humans showed that the gut microbiota participates in the 5-HT production and influences the serotonergic neuronal networks $[125,126]$. Mechanistically, some studies have revealed that gut microbiota-derived SCFAs increase the circulating 5-HT concentration via promoting tryptophan hydroxylase (Tph) 1 transcription in ECs [126, 127], whereas Martin et al. reported that acetate or butyrate treatment fails to affect the 5-HT secretion in duodenal and colonic ECs [128]. Additionally, a recent study showed that indole and its derivate, indole-3carboxaldehyde (IA1d), produced by Edwardsiella tarda, form Trp that can bind with transient receptor potential ankyrin Aa (Trpa1) to enhance 5-HT secretion from enteroendocrine cells, and in turn stimulates intestinal motility and regulates CNS function in both human and mouse models [129]. Moreover, other microbial metabolites, such as deoxycholate, $\alpha$-tocopherol, $\mathrm{p}$ aminobenzoate, and tyramine, also can stimulate the 5HT secretion from ECs and enteric neurons [122, 126, 130]. Approximately $90 \%$ of the circulating $5-\mathrm{HT}$ is produced from enterochromaffin cells (ECs) in the host gut and then stored in circulating platelets that convey 5HT into every organ and tissue, including the brain [126]. Thus, although 5-HT cannot cross the BBB directly, platelet-derived $5-\mathrm{HT}$ is able to increase the level of CNS 5-HT, which might link the intestinal 5-HT with brain function [131]. Various studies have shown that 5HT plays a vital role in regulating energy metabolism and suppressing appetite through various mechanisms, including improving insulin sensitivity and mediating intestinal functions (i.e., motility, secretion, absorption, and sensory) by directly acting on the enteric nervous system and hypothalamic AgRP and POMC neurons 
[132-139]. Thus, it is clear that the gut microbiota can involve in appetite control by modulating intestinal and central 5-HT signaling.

In summary, gut microbial regulation of Trp metabolism involves in host appetite control (Fig. 2), although these effects are somewhat inconsistent and the reasons remain unclear, but might be partially due to whether the stimulation of Trp reach the "threshold" required to regulate appetite and energy intake. These findings encourage the future investigation of the specific role and mechanism of Trp and its metabolites derived from gut microbiota in appetite control.

\section{GABA}

GABA is a microbial metabolite from dietary glutamate and acts as a neurotransmitter that contributes to the communication between the gastrointestinal tract and brain [140]. Most Lactobacilli and Bifidobacteria strains have the Gad genes that can encode glutamate decarboxylase to synthesize GABA [141, 142]. Obese patients have decreased abundance of glutamate-fermenting microbiota, as well as increased circulating glutamate level [143], indicating that the gut microbiota participates in host energy hemostasis through modulating glutamate metabolism. This hypothesis is further confirmed by studies using GF, gnotobiotic, and humanized mice [144-146].

GABA is strongly associated with appetite control as the disruption of GABA signaling pathways can inhibit postweaning feeding, blunted NPY-induced hyperphagia, and hunger-induced appetite [147, 148]. Mechanistically, GABA has long been known as a molecular signal involved in modulating the gastrointestinal motility and the secretion of appetite-related hormones (extensively reviewed elsewhere [149]). In addition, GABA functions as an inhibitory neurotransmitter in the CNS. GABA is required, at least in part, to the activation of AgRP neurons $[150,151]$. It is noteworthy that due to the variation of chemicals and compounds and the different administration methods, the data on whether GABA can cross the BBB is inconsistent [152-154]. In addition, the majority of studies demonstrating the effects of GABA on host health focus on dietary GABA rather than host endogenic GABA. The rumen-protected GABA supplementation increases feed intake and inhibits CCK signaling in growing lambs and cows $[155,156]$, which may be because GABA is co-expressed and shares the similar signal transduction pathways with CCK $[150,156,157]$. Thus, it does appear to be reasonable to hypothesize that GABA might be involved in the appetite control via acting on its receptors in the gastrointestinal tract and brain, which in turn influences the secretion of gut hormones and activates central neurons, respectively. However, the research on the relationship between the gut microbial-derived GABA and appetite control is limited; thus, further studies are needed to investigate the role of GABA produced by the gut microbiota on host metabolic health and determine whether GABA can cross the $\mathrm{BBB}$ and act on the CNS to regulate appetite.

\section{BCAAs}

BCAAs, including leucine, isoleucine, and valine, are derived from the diet as well as can be de novo by the gut microbiota. The gut microbiota exhibits enriched genes related to BCAA biosynthesis (Prevotella copri and Bacteroides vulgatus), degradation (Bacteroides thetaiotaomicron and Dorea longicatena), and uptake (Butyrivibrio crossotus and Eubacterium siraeum) [158, 159]. Human and animal studies revealed the relationship between gut microbiota, circulating BCAA level, and insulin resistance [160-164]. There is also growing evidence that demonstrates that dietary supplementation or reduction of BCAAs induces alterations in host appetite, yielding inconsistent results. For example, long-term BCAA supplementation decreases feed intake in high-fat dietinduced obese rats [165]. Diet containing high ratio of BCAAs to other AAs (non-BCAAs) induces hyperphagia in mice, which might be because high BCAAs: nonBCAAs intake downregulates the synthesis of central 5HT [166]. Our recent study also found that supplementation of BCAAs to low-protein diet increases the relative abundance of colonic Lactobacillales and promotes food intake in piglets [167]. Furthermore, in another study using piglets, long-term dietary deficiency of BCAAs inhibits food intake which might be associated with the enhanced expression of intestinal amino acid receptors, type-1 taste receptors 1 (T1R1) and type-1 taste receptors T1R3, that can activate the CCK secretion and the enhanced hypothalamic GCN2-Eif2 $\alpha$ signaling that is involved in the energy metabolism and inhibiting appetite [168]. We speculate that the inconsistent results might be due in part to whether the studies involve the manipulation of the balance between the BCAAs and non-BCAAs. Although, the mechanism by which BCAAs involve in appetite control are complex and controversial (Fig. 2), these data suggest that targeting at gut microbiota for maintaining amino acid metabolism and homeostasis might be crucial for improving appetite control.

\section{BAs}

BAs are synthesized in the liver and released into the gastrointestinal tract and are involved in intestinal absorption of lipid, as well as metabolic and inflammatory signaling pathways [169]. Previous studies have shown that the gut microbiota plays a crucial role in the BA metabolism by deconjugation, dehydrogenation, and dihydroxylation of primary BAs [170-172]. The 
synthesis of BAs mainly depends on cholesterol $7 \alpha$ hydroxylase (CYP7A1) and sterol-27-hydroxylase (CYP27A1) that are regulated by the gut microbiota $[173,174]$. Moreover, BAs have been reported to modulate appetite by directly binding with their receptors in the gastrointestinal tract to regulate the secretion of appetite-associated hormones. For example, altered BA composition enhances the GLP-1 and PYY secretion from enteroendocrine cells via activating GRP119 and Takeda G-protein-coupled bile acid receptor (TGR5) in ECs, which in turn slows gastric emptying and ultimately decreases food intake in mice $[175,176]$. Collectively, it is reasonable to conclude that BA metabolism, which is greatly affected by the gut microbiota, can mediate appetite regulation by modulating appetite-related hormones.

\section{Gut bacterial proteins}

The gut microbiota, including the bacteria, fungi, virus, and archaea, can produce identical protein sequences with appetite-regulating peptides (i.e., leptin, PYY, ghrelin, $\alpha-\mathrm{MSH}$, NPY, AgRp) [177]. ClpB, the best studied bacterial protein, can act as a mimetic of alphamelanocyte-stimulating hormone $(\alpha-\mathrm{MSH})$ to result in similar anorexigenic effects [178]. Briefly, ClpB derived from Escherichia coli (E. coli) is capable of displaying the $\alpha-\mathrm{MSH}$-like function, such as enhancing PYY and GLP1 secretion, and directly activating anorexigenic neurons, and subsequently inducing satiety [13, 48]. An in vitro study showed that protein supplementation stimulates the secretion of ClpB from E. coli, which can induce satiety signaling by enhancing the PYY production in intestinal mucosal cells [179]. This observation was translated to rats treated with protein produced by $E$. coli showing inhibited host appetite, increased circulating GLP-1 and PYY concentrations, and activated hypothalamic POMC neurons, which may be due to the anorexigenic functions of $\mathrm{ClpB}$ [13]. In addition, a recent study revealed that food restriction increases plasma $\mathrm{ClpB}$ levels, which is associated with the increased relative abundance of Enterobacteriaceae and intestinal permeability, and in turn increases satiety by activating anorexigenic neurons in mice [96]. Altogether, these data support the possible mechanistic links between gut microbiota-derived $\mathrm{ClpB}$ and host appetite. Whether other specific gut microbial communities also can produce $\mathrm{ClpB}$ and contribute to appetite control is unknown.

The gut microbiota play a key role in regulating the immunoglobulin (Ig) production (reviewed in detail elsewhere [180]). Igs can react with $\alpha-\mathrm{MSH}$ and then activate $\mathrm{MC} 4 \mathrm{R}$ to involve in appetite control, which can be diminished by ClpB through neutralizing IgG $[180,181]$. IgG has been reported to involve in controlling appetite by modulating leptin and ghrelin signaling pathways
[182, 183]. Co-administration of ghrelin together with IgG from obese patients and ob/ob mice increased food intake in mice, which might be due to the inhibited ghrelin degradation induced by ghrelin-reactive IgG [183]. Another study revealed that the levels of plasma IgG and $\alpha-\mathrm{MSH}$ were lower in rats with methotrexateinduced intestinal inflammation and anorexia, while anti- $\alpha-\mathrm{MSH}$ IgG supplementation led to an attenuation of feed intake [184]. Besides, AN patients show higher levels of $\alpha$-MSH-reactive IgM and $\alpha-\mathrm{MSH}-\mathrm{IgG}$ complexes that can bind and activate MC4R with a lower threshold than $\alpha-\mathrm{MSH}$ alone than normal controls [185, 186]. Additionally, a recent study revealed that the activation of the mechanistic target of rapamycin complex 1 (mTORC1) signaling can modulate IgA secretion, which contributes to decreased Lactobacillus johnsonii Q1-7 abundance and inhibited food intake in mice [187]. These data suggest a link between the gut microbiota, autoimmune system, and appetite control. These bacterial proteins could be used as biomarkers of eating disorders but needs further confirmation.

\section{Clinical relevance}

Abnormal regulation of appetite can cause eating disorders and obesity [188-190], which are severe and lifethreating mental illness. In a study of Australian adolescents, $22.2 \%$ of participants suffered from eating disorders [191]. AN, BN, and binge eating disorders (BED) are the three most common eating disorder diagnoses. The most common explanation for AN is the constant fear of becoming overweight and disturbed cognitions about body perception [192]. Individuals with AN show severe underweight, and other psychiatric complications include depression and anxiety [7, 193]. An increasing number of studies indicate that individuals with $\mathrm{BN}$ and binge eating disorders have higher incidence rates of obesity and related metabolic diseases, such as type 2 diabetes and cardiovascular disease compared to individuals with no history of eating disorders [194-196].

In recent years, there has been keen interest in exploring the gut-microbiota-brain axis [197-201]. Growing evidence suggests that the gut microbiota can act as an effective regulator of host body weight and psychiatric disorders [140, 202-205]. Fecal microbiota transplantation (FMT) from a healthy individual to an AN patient has led to weight gain by increasing the production of SCFAs and composition of beneficial microbiota [69]. Besides, gut viral community contains mostly phages, which can infect bacteria and lead to cell lysis [206]. Similar to FMT, a recent study has mounted that fecal virome transplantation (FVT) also has therapeutic potential against metabolic diseases, including obesity and T2D [207]. Another series of studies demonstrated that administration of prebiotics and probiotics have the 
ability to regulate food intake and ameliorate obesity and associated disorders in humans and experimental animals [208-210] (Table 1). However, the effects of probiotics on appetite-related hormones and appetite in obese and overweight subjects are inconsistent, which has been reviewed elsewhere recently [211]. Thus, future studies with high methodological quality and low risk of bias are needed to determine precise the effects of probiotics on appetite regulation. In addition to the common probiotics (mainly include Lactobacillus spp. and Bifidobacterium spp.), the next-generation probiotics (i.e. Akkermansia muciniphila, Bacteroides thetaiotaomicron, Bacteroides vulgatus, Faecalibacterium prausnitzii, Ruminococcus bromii, and Roseburia) have been gradually identified and considered to have the potential for treating metabolic diseases due to the development of culturing methodologies and genome and metagenome sequencing techniques [93, 212-217]. Despite the technologies limit the use of the new identified probiotics, it may provide opportunities to use dietary interventions, such as prebiotics, to treat appetite-related disorders via modulating specific gut microbiota [218]. In a recent study, Ortega-Vega et al. found that the gut microbial diversity and some specific gut microbiota with heritability are associated with the variants in these genes encoding ghrelin, MC4R, GLP-1, NPY, and PYY and metabolic diseases, revealing that, to some extent, the intricate links between host genetics and gut microbiota are related to appetite modulation, which expands our understanding of the functional attributes of the gut

Table 1 Studies on probiotics/prebiotics and appetite control in human and animals

\begin{tabular}{|c|c|c|c|}
\hline & $\begin{array}{l}\text { Human/ } \\
\text { animal }\end{array}$ & Effects & References \\
\hline \multicolumn{4}{|l|}{ Probiotics } \\
\hline Lactobacillus paracasei & Men & Decreased food intake & [220] \\
\hline $\begin{array}{l}\text { Lactobacillus acidophilus, Bifidobacterium bifidum, } \\
\text { Bifidobacterium lactis, Bifidobacterium longum, Lactobacillus } \\
\text { rhamnosus, Lactobacillus reuteri, magnesium stearate, and } \\
\text { maltodextrin }\end{array}$ & Women & $\begin{array}{l}\text { Decreased hunger score and emotional eating score } \\
\text { by inhibiting NPY }\end{array}$ & [221] \\
\hline Lactobacillus acidophilus and Lactobacillus casei & Broiler chicken & Decreased feed intake & [222] \\
\hline Hafnia alvei HA4597 & $\begin{array}{l}\text { High-fat-diet- } \\
\text { fed obese } \\
\text { mice }\end{array}$ & Decreased feed intake by increasing ClpB production & [223] \\
\hline Lactobacillus brevis SBC883 & Rats & $\begin{array}{l}\text { Increasing feed intake by increasing serotonin and } \\
\text { ghrelin production }\end{array}$ & [224] \\
\hline Lactobacillus casei & $\begin{array}{l}\text { Children with } \\
\text { diarrhea }\end{array}$ & $\begin{array}{l}\text { Improved appetite by altering gut microbiota (i.e. } \\
\text { increased Bifidobacteria and Lactobacillus) }\end{array}$ & [225] \\
\hline Lactobacillus rhamnosus & Larvae & $\begin{array}{l}\text { Increased feed intake by altering gut microbiota and } \\
\text { neuropeptide production }\end{array}$ & [226] \\
\hline $\begin{array}{l}\text { Lactobacillus rhamnosus, L. acidophilus, and Bifidobacterium } \\
\text { bifidum }\end{array}$ & $\begin{array}{l}\text { Diet-induced } \\
\text { obese mice }\end{array}$ & $\begin{array}{l}\text { Decreased feed intake by altering gut microbiota and } \\
\text { decreasing intestinal permeability }\end{array}$ & [227] \\
\hline Lactobacillus rhamnosus & Obese women & Decreased desire to eat & [228] \\
\hline Lactobacillus rhamnosus & Zebrafish & Decreased appetite by altering gut microbiota & [229] \\
\hline \multicolumn{4}{|l|}{ Prebiotics } \\
\hline Oligofructose-enriched inulin & $\begin{array}{l}\text { Children with } \\
\text { overweight/ } \\
\text { obesity }\end{array}$ & $\begin{array}{l}\text { Decreased food intake by decreasing ghrelin and } \\
\text { increasing PYY }\end{array}$ & [56] \\
\hline Inulin-type fructans and/or whey protein & $\begin{array}{l}\text { Adults with } \\
\text { overweight/ } \\
\text { obesity }\end{array}$ & $\begin{array}{l}\text { Decreased hunger, desire to eat, and prospective food } \\
\text { consumption by altering gut microbiota (i.e., increased } \\
\text { Bifidobacterium) }\end{array}$ & [230] \\
\hline Chicory & Mice & $\begin{array}{l}\text { Induced satiety by altering gut microbiota (i.e., } \\
\text { Firmicutes/Bacteroidetes ratio, Alloprevotella, Blautia) and } \\
\text { increasing CCK and GLP-1 }\end{array}$ & [231] \\
\hline Mannose oligosaccharide & $\begin{array}{l}\text { Diet-induced } \\
\text { obese mice }\end{array}$ & $\begin{array}{l}\text { Suppressed appetite by altering gut microbiota (i.e., } \\
\text { increased Bifidobacterium and Lactobacillus) and } \\
\text { increased SCFAs production }\end{array}$ & [232] \\
\hline Digestion-resistant maltodextrin/fructooligosaccharides & $\begin{array}{l}\text { Diet-induced } \\
\text { obese rats }\end{array}$ & $\begin{array}{l}\text { Decreased energy intake by increasing GLP-1 } \\
\text { production }\end{array}$ & [233] \\
\hline
\end{tabular}


microbiome in metabolic and eating disorders as well as open new therapeutic manipulation of specific microbiota [219].

Although there is as yet no evidence that such treatments would be safe and efficient for feeding-related diseases, these studies provide proof of concept for microbial interventions in directly or indirectly counteracting eating disorders (Fig. 3). While the mechanism by which how the gut microbiota may regulate eating behavior is still elusive, efforts to alter the commensal microbiota by administration of probiotic, prebiotic, phage, and even FMT highlight the potential of microbiota interventions in treating eating disorders by modulating host appetite and reducing food-related and body-related fears; the potential of microbiota as a modifier of metabolic disorders induced by abnormal appetite control; and the potential of microbial amelioration of psychiatric diseases such as depression and anxiety caused by eating disorders.

\section{Conclusions}

In this review, the direct and indirect molecular mechanisms how the gut microbiota regulates host appetite were summarized. Although a great number of studies have already linked the gut microbiota and eating behavior, the precise mechanisms through which the gut microbiota influence particular eating disorders, such as anorexia nervosa and food addiction, have not yet been fully deciphered. Understanding how some specific members of the gut microbiota are involved in appetite control may be important to develop novel preventive and therapeutic interventions and even prediction for eating disorders. It should be noted that it is extremely difficult to define the optimal gut microbiota, since individuals have different gut microbiota composition, and even in the same host, the gut microbiota have complex variations and evolutions during the whole life cycle due to various diets, environments, genes' expression, and so on [234-239]. The gut microbiota could be the so-called healthy microbiota as long as it benefits the individual who harbors it. Thus, further efforts should be made to explore the dynamics and effects of gut microbiota changes and differences, in order to design microbiotabased therapeutic strategies for different individuals during different life stages. To date, our understanding of the gut microbiota roles in modulating appetite is mainly based on in vitro studies and rodent models. With regard to this, it will be essential to conduct well-designed clinical trials or assemble clinical data, in order to fill the large gaps between clinical and experimental knowledge and translate the proof of concept acquired from animal models to the clinical setting. Consequently, these studies may potentially be applied for probiotics, prebiotics applications, and FMT, as an effective treatment for eating-related diseases in the future.

\section{Abbreviations}

AN: Anorexia nervosa; BN: Bulimia nervosa; SCFAs: Short-chain fatty acids; GRP43: Free fatty acid receptor 2; GRP41: Free fatty acid receptor 3; GLP1: Glucagon-like peptide; PYY: peptide YY; POMC: Pro-opiomelanocortin; MSH: Melanocyte-stimulating hormone; MC4R: Melanocortin-4 receptor; GABA: $\gamma$-aminobutyric acid; AgRP: Agouti-related peptide; ARC: Arcuate nucleus; Trp: Tryptophan; 5-HT: Serotonin, 5-hydroxytryptamine; NPY: Neuropeptide Y; GH-IGF: Growth hormone-insulin-like growth factor; CCK: Cholecystokinin; BAs: Bile acids; GF: Germ-free; FXR: Farnesoid X receptor; TGR5: Takeda G-protein-coupled bile acid receptor; CART: Amphetamine-regulated transcript; WT: Wild-type;

Angpt14: Angiopoietin-like protein 14; ClpB: Caseinolytic protease; TLRs: Tolllike receptors; PAMPs: Pathogen-associated molecular patterns;

LPS: Lipopolysaccharide; Igs: Immunoglobulins; mTORC1: Mtormechanistic target of rapamycin complex 1; ABA: Activity-based anorexia

\section{Acknowledgements}

The authors would like to acknowledge and thank Nadia Everaert and Yong Zhao for their help editing this manuscript.

\section{Authors' contributions}

$\mathrm{HH}$ and BY wrote the first draft of the manuscript. RQZ, SFZ, JM, NE, and JY helped to review the first draft of the manuscript. $Y L Y, Y Z, J Y, L C$, and HFZ reviewed and edited the final manuscript. The authors read and approved the final manuscript.

\section{Funding}

The authors acknowledge the financial support from the National Natural Science Foundation (31702119, 31672428), Agricultural Science and Technology Innovation Program (CAAS-ZDRW202006-02, ASTIP-IAS07), and Central Public-interest Scientific Institution Basal Research Fund (Y2021GH014) in China.

\section{Availability of data and materials}

Data sharing not applicable to this article as no datasets were generated or analyzed during the current study.

\section{Declarations}

Ethics approval and consent to participate

Not applicable.

\section{Consent for publication}

Not applicable.

\section{Competing interests}

The authors declare that they have no competing interests.

\section{Author details}

${ }^{1}$ State Key Laboratory of Animal Nutrition, Institute of Animal Science, Chinese Academy of Agricultural Sciences, Beijing 100193, China. ${ }^{2}$ Precision Livestock and Nutrition Unit, Gembloux Agro-Bio Tech, University of Liège, Passage de Déportés 2, 5030 Gembloux, Belgium. ${ }^{3}$ College of Animal Science and Technology, Hunan Agricultural University, Changsha 410128, China.

${ }^{4}$ Key Laboratory of Agro-Ecological Processes in Subtropical Region, Institute of Subtropical Agriculture, Chinese Academy of Sciences, Changsha, Hunan 410125, China.

Received: 8 April 2021 Accepted: 11 May 2021

Published online: 20 July 2021

\section{References}

1. Noble EE, Hahn JD, Konanur VR, Hsu TM, Page SJ, Cortella AM, et al. Control of feeding behavior by cerebral ventricular volume transmission of melaninconcentrating hormone. Cell Metab. 2018;28:55-68.e7.

2. Aklan I, Sayar Atasoy N, Yavuz Y, Ates T, Coban I, Koksalar F, et al. NTS catecholamine neurons mediate hypoglycemic hunger via medial hypothalamic feeding pathways. Cell Metab. 2020;31:313-326.e5.

3. Tan HE, Sisti AC, Jin H, Vignovich M, Villavicencio M, Tsang KS, et al. The gut-brain axis mediates sugar preference. Nature. 2020;580:511-6. 
4. Simon JJ, Stopyra MA, Mönning E, Sailer S, Lavandier N, Kihm L, et al. Neuroimaging of hypothalamic mechanisms related to glucose metabolism in anorexia nervosa and obesity. J Clin Invest. 2020;130:4094-103.

5. Andermann ML, Lowell BB. Toward a wiring diagram understanding of appetite control. Neuron. 2017;95:757-78.

6. Zhang R, Larsen JT, Kuja-Halkola R, Thornton L, Yao S, Larsson H, et al. Familial co-aggregation of schizophrenia and eating disorders in Sweden and Denmark. Mol Psychiatry. 2020. https://doi.org/10.1038/s41380-020-074 $9-x$.

7. Kaye WH, Wierenga CE, Bischoff-Grethe A, Berner LA, Ely AV, Bailer UF, et al. Neural insensitivity to the effects of hunger in women remitted from anorexia nervosa. Am J Psychiatry. 2020;177:601-10.

8. Stanghellini G. Embodiment and the other's look in feeding and eating disorders. World Psychiatry. 2019;18:364-5.

9. Watson HJ, Yilmaz Z, Thornton LM, Hubel C, Coleman JRI, Gaspar HA, et al Genome-wide association study identifies eight risk loci and implicates metabo-psychiatric origins for anorexia nervosa. Nat Genet. 2019;51:120714.

10. Fetissov SO. Role of the gut microbiota in host appetite control: bacterial growth to animal feeding behaviour. Nat Rev Endocrinol. 2017;13:11-25.

11. Hanachi M, Manichanh C, Schoenenberger A, Pascal V, Levenez F, Cournède $\mathrm{N}$, et al. Altered host-gut microbes symbiosis in severely malnourished anorexia nervosa (AN) patients undergoing enteral nutrition: an explicative factor of functional intestinal disorders? Clin Nutr. 2019;38:2304-10.

12. Hankir MK, Seyfried F, Hintschich CA, Diep TA, Kleberg K, Kranz M, et al. Gastric bypass surgery recruits a gut PPAR-alpha-striatal D1R pathway to reduce fat appetite in obese rats. Cell Metab. 2017;25:335-44.

13. Breton J, Tennoune N, Lucas N, Francois M, Legrand R, Jacquemot J, et al. Gut commensal E. coli proteins activate host satiety pathways following nutrient-induced bacterial growth. Cell Metab. 2016;23:324-34.

14. Breton J, Tirelle P, Hasanat S, Pernot A, L'Huillier C, do Rego JC, et al. Gut microbiota alteration in a mouse model of anorexia nervosa. Clin Nutr. 2020;40:181-9.

15. Greenhill C. Gut microbiota: proteins released by E. coli in the gut influence host appetite control. Nat Rev Endocrinol. 2016;12:4.

16. Sharon G, Cruz NJ, Kang DW, Gandal MJ, Wang B, Kim YM, et al. Human gut microbiota from autism spectrum disorder promote behavioral symptoms in mice. Cell. 2019;177:1600-1618.e17.

17. Grasset E, Puel A, Charpentier J, Collet X, Christensen JE, Terce F, et al. A specific gut microbiota dysbiosis of type 2 diabetic mice induces GLP-1 resistance through an enteric NO-dependent and gut-brain axis mechanism. Cell Metab. 2017:25:1075-1090.e5.

18. Morita C, Tsuji H, Hata T, Gondo M, Takakura S, Kawai K, et al. Gut dysbiosis in patients with anorexia nervosa. Plos One. 2015;10:e0145274.

19. Kleiman SC, Watson HJ, Bulik-Sullivan EC, Huh EY, Tarantino LM, Bulik CM, et al. The intestinal microbiota in acute anorexia nervosa and during renourishment: relationship to depression, anxiety, and eating disorder psychopathology. Psychosom Med. 2015;77:969-81.

20. Mack I, Cuntz U, Gramer C, Niedermaier S, Pohl C, Schwiertz A, et al. Weight gain in anorexia nervosa does not ameliorate the faecal microbiota, branched chain fatty acid profiles, and gastrointestinal complaints. Sci Rep. 2016;6:26752.

21. Breton J, Legrand R, Akkermann $K$, Järv A, Harro J, Déchelotte $P$, et al. Elevated plasma concentrations of bacterial ClpB protein in patients with eating disorders. Int J Eat Disord. 2016;49:805-8.

22. Yin J, Han H, Li Y, Liu Z, Zhao Y, Fang R, et al. Lysine restriction affects feed intake and amino acid metabolism via gut microbiome in piglets. Cell Physiol Biochem. 2017:44:1749-61.

23. Khera AV, Emdin CA, Drake I, Natarajan P, Bick AG, Cook NR, et al. Genetic risk, adherence to a healthy lifestyle, and coronary disease. N Engl J Med. 2016;375:2349-58.

24. Barabási A-L, Menichetti G, Loscalzo J. The unmapped chemical complexity of our diet. Nature Food. 2020;1:33-7.

25. van de Wouw M, Schellekens H, Dinan TG and Cryan JF. Microbiota-GutBrain Axis: Modulator of Host Metabolism and Appetite. J Nutr. 2017;147: 727-45.

26. TO K, Carli JF, Skowronski AA, Sun Q, Kriebel J, Feitosa MF, et al. Genomewide meta-analysis uncovers novel loci influencing circulating leptin levels. Nat Commun. 2016;7:10494.

27. Park S, Aintablian A, Coupe B, Bouret SG. The endoplasmic reticulum stressautophagy pathway controls hypothalamic development and energy balance regulation in leptin-deficient neonates. Nat Commun. 2020;11:1914.
28. Rasmussen BA, Breen DM, Duca FA, Côté CD, Zadeh-Tahmasebi M, Filippi BM, et al. Jejunal leptin-PI3K signaling lowers glucose production. Cell Metab. 2014;19:155-61.

29. Sobhani I, Bado A, Vissuzaine C, Buyse M, Kermorgant S, Laigneau JP, et al Leptin secretion and leptin receptor in the human stomach. Gut. 2000;47: 178-83.

30. Banks WA. The blood-brain barrier as an endocrine tissue. Nat Rev Endocrinol. 2019;15:444-55.

31. Elefteriou F, Ahn JD, Takeda S, Starbuck M, Yang X, Liu X, et al. Leptin regulation of bone resorption by the sympathetic nervous system and CART. Nature. 2005;434:514-20.

32. Yang $Y$, van der Klaauw AA, Zhu L, Cacciottolo TM, He Y, Stadler LKJ, et al. Steroid receptor coactivator-1 modulates the function of Pomc neurons and energy homeostasis. Nat Commun. 2019;10:1718.

33. $\mathrm{Xu}$ J, Bartolome $\mathrm{CL}$, Low CS, Yi X, Chien CH, Wang P, et al. Genetic identification of leptin neural circuits in energy and glucose homeostases. Nature. 2018:556:505-9.

34. Cedernaes J, Huang W, Ramsey KM, Waldeck N, Cheng L, Marcheva B, et al. Transcriptional basis for rhythmic control of hunger and metabolism within the AgRP neuron. Cell Metab. 2019;29:1078-91 e5.

35. Le Chatelier E, Nielsen T, Qin J, Prifti E, Hildebrand F, Falony G, et al. Richness of human gut microbiome correlates with metabolic markers. Nature. 2013:500:541-6.

36. Amar J, Chabo C, Waget A, Klopp P, Vachoux C, Bermúdez-Humarán LG, et al. Intestinal mucosal adherence and translocation of commensal bacteria at the early onset of type 2 diabetes: molecular mechanisms and probiotic treatment. EMBO Mol Med. 2011;3:559-72.

37. Massier L, Chakaroun R, Tabei S, Crane A, Didt KD, Fallmann J, et al. Adipose tissue derived bacteria are associated with inflammation in obesity and type 2 diabetes. Gut. 2020;69:1796-806.

38. Schéle E, Grahnemo L, Anesten F, Hallén A, Bäckhed F, Jansson J-O. The gut microbiota reduces leptin sensitivity and the expression of the obesitysuppressing neuropeptides proglucagon (Gcg) and brain-derived neurotrophic factor (Bdnf) in the central nervous system. Endocrinology. 2013;154:3643-51.

39. Yao H, Fan C, Fan X, Lu Y, Wang Y, Wang R, et al. Effects of gut microbiota on leptin expression and body weight are lessened by high-fat diet in mice. Br J Nutr. 2020;124:396-406.

40. Backhed F, Ding H, Wang T, Hooper LV, Koh GY, Nagy A, et al. The gut microbiota as an environmental factor that regulates fat storage. Proc Natl Acad Sci U S A. 2004;101:15718-23.

41. Lee J, Jang JY, Kwon MS, Lim SK, Kim N, Lee J, et al. Mixture of two Lactobacillus plantarum strains modulates the gut microbiota structure and regulatory T cell response in diet-induced obese mice. Mol Nutr Food Res. 2018:62:e1800329.

42. Song $X$, Zhong L, Lyu N, Liu F, Li B, Hao Y, et al. Inulin can alleviate metabolism disorders in ob/ob mice by partially restoring leptin-related pathways mediated by gut microbiota. Genomics Proteomics Bioinformatics. 2019:17:64-75.

43. Al-Muzafar HM, Amin KA. Probiotic mixture improves fatty liver disease by virtue of its action on lipid profiles, leptin, and inflammatory biomarkers. BMC Complement Altern Med. 2017;17:43.

44. Bagarolli RA, Tobar N, Oliveira AG, Araujo TG, Carvalho BM, Rocha GZ, et al. Probiotics modulate gut microbiota and improve insulin sensitivity in DIO mice. J Nutr Biochem. 2017:50:16-25.

45. Swisa A, Avrahami D, Eden N, Zhang J, Feleke E, Dahan T, et al. PAX6 maintains $\beta$ cell identity by repressing genes of alternative islet cell types. J Clin Invest. 2017;127:230-43.

46. Cowley MA, Smith RG, Diano S, Tschöp M, Pronchuk N, Grove KL, et al. The distribution and mechanism of action of ghrelin in the CNS demonstrates a nove hypothalamic circuit regulating energy homeostasis. Neuron. 2003;37:649-61.

47. Date $Y$, Murakami N, Toshinai $K$, Matsukura S, Niijima A, Matsuo H, et al. The role of the gastric afferent vagal nerve in ghrelin-induced feeding and growth hormone secretion in rats. Gastroenterology. 2002;123:1120-8.

48. Panaro BL, Tough IR, Engelstoft MS, Matthews RT, Digby GJ, Moller CL, et al. The melanocortin-4 receptor is expressed in enteroendocrine $L$ cells and regulates the release of peptide $Y Y$ and glucagon-like peptide 1 in vivo. Cell Metab. 2014:20:1018-29.

49. Kuhnen P, Krude H, Biebermann H. Melanocortin-4 receptor signalling: importance for weight regulation and obesity treatment. Trends Mol Med. 2019:25:136-48 
50. Suarez AN, Liu CM, Cortella AM, Noble EE, Kanoski SE. Ghrelin and orexin interact to increase meal size through a descending hippocampus to hindbrain signaling pathway. Biol Psychiatry. 2020;87:1001-11.

51. Theander-Carrillo C, Wiedmer P, Cettour-Rose P, Nogueiras R, Perez-Tilve D, Pfluger $P$, et al. Ghrelin action in the brain controls adipocyte metabolism. J Clin Invest. 2006;116:1983-93.

52. Perry RJ, Peng L, Barry NA, Cline GW, Zhang D, Cardone RL, et al. Acetate mediates a microbiome-brain- $\beta$-cell axis to promote metabolic syndrome. Nature. 2016;534:213-7.

53. Torres-Fuentes C, Golubeva AV, Zhdanov AV, Wallace S, Arboleya S, Papkovsky DB, et al. Short-chain fatty acids and microbiota metabolites attenuate ghrelin receptor signaling. FASEB J. 2019;33:13546-59.

54. Parnell JA, Reimer RA. Weight loss during oligofructose supplementation is associated with decreased ghrelin and increased peptide $Y Y$ in overweight and obese adults. Am J Clin Nutr. 2009:89:1751-9.

55. Cani PD, Lecourt E, Dewulf EM, Sohet FM, Pachikian BD, Naslain D, et al. Gut microbiota fermentation of prebiotics increases satietogenic and incretin gut peptide production with consequences for appetite sensation and glucose response after a meal. Am J Clin Nutr. 2009;90:1236-43.

56. Hume MP, Nicolucci AC, Reimer RA. Prebiotic supplementation improves appetite control in children with overweight and obesity: a randomized controlled trial. Am J Clin Nutr. 2017;105:790-9.

57. Berthoud HR. Metabolic and hedonic drives in the neural control of appetite: who is the boss? Curr Opin Neurobiol. 2011;21:888-96.

58. Leidmaa E, Gazea M, Patchev AV, Pissioti A, Christian Gassen N, Kimura M, et al. Blunted leptin sensitivity during hedonic overeating can be reinstated by activating galanin 2 receptors (Gal2R) in the lateral hypothalamus. Acta Physiol (Oxf). 2020;228:e13345.

59. Zhang $X$, van den Pol AN. Rapid binge-like eating and body weight gain driven by zona incerta GABA neuron activation. Science. 2017;356:853-9.

60. Murphy KG, Bloom SR. Gut hormones and the regulation of energy homeostasis. Nature. 2006:444:854-9.

61. van Golen LW, ljzerman RG, Huisman MC, Hensbergen JF, Hoogma RP Drent $\mathrm{ML}$, et al. Cerebral blood flow and glucose metabolism in appetiterelated brain regions in type 1 diabetic patients after treatment with insulin detemir and NPH insulin: a randomized controlled crossover trial. Diabetes Care. 2013;36:4050-6.

62. Loh K, Zhang L, Brandon A, Wang Q, Begg D, Qi Y, et al. Insulin controls food intake and energy balance via NPY neurons. Mol Metab. 2017;6:57484.

63. Hallschmid M, Higgs S, Thienel M, Ott V, Lehnert H. Postprandial administration of intranasal insulin intensifies satiety and reduces intake of palatable snacks in women. Diabetes. 2012;61:782-9.

64. Kim HK, Youn BS, Shin MS, Namkoong C, Park KH, Baik JH, et al. Hypothalamic Angpt/4/Fiaf is a novel regulator of food intake and body weight. Diabetes. 2010;59:2772-80.

65. Suarez-Zamorano N, Fabbiano S, Chevalier C, Stojanovic O, Colin DJ, Stevanovic A, et al. Microbiota depletion promotes browning of white adipose tissue and reduces obesity. Nat Med. 2015:21:1497-501.

66. Zarrinpar A, Chaix A, Xu ZZ, Chang MW, Marotz CA, Saghatelian A, et al. Antibiotic-induced microbiome depletion alters metabolic homeostasis by affecting gut signaling and colonic metabolism. Nat Commun. 2018;9:2872.

67. Li X, Wang E, Yin B, Fang D, Chen P, Wang G, et al. Effects of Lactobacillus casei CCFM419 on insulin resistance and gut microbiota in type 2 diabetic mice. Benef Microbes. 2017:8:421-32.

68. Mao JH, Kim YM, Zhou YX, Hu D, Zhong C, Chang H, et al. Genetic and metabolic links between the murine microbiome and memory. Microbiome. 2020;8:53.

69. de Clercq NC, Frissen MN, Davids M, Groen AK and Nieuwdorp M. Weight Gain after Fecal Microbiota Transplantation in a Patient with Recurrent Underweight following Clinical Recovery from Anorexia Nervosa. Psychother Psychosom. 2019;88:58-60.

70. Yang $H$, Yang $M$, Fang $S$, Huang $X$, He M, Ke $S$, et al. Evaluating the profound effect of gut microbiome on host appetite in pigs. BMC Microbiol. 2018;18:215

71. Liu JL, Segovia I, Yuan XL and Gao ZH. Controversial Roles of Gut Microbiota-Derived Short-Chain Fatty Acids (SCFAs) on Pancreatic $\beta$-Cell Growth and Insulin Secretion. Int J Mol Sci. 2020;21:910.

72. Perry RJ, Peng L, Barry NA, Cline GW, Zhang D, Cardone RL, et al. Acetate mediates a microbiome-brain-beta-cell axis to promote metabolic syndrome. Nature. 2016;534:213-7.
73. Priyadarshini M, Navarro $G$ and Layden BT. Gut Microbiota: FFAR Reaching Effects on Islets. Endocrinology. 2018;159:2495-2505.

74. Chambers ES, Viardot A, Psichas A, Morrison DJ, Murphy KG, Zac-Varghese $\mathrm{SE}$, et al. Effects of targeted delivery of propionate to the human colon on appetite regulation, body weight maintenance and adiposity in overweight adults. Gut. 2015:64:1744-54

75. Bolognini D, Barki N, Butcher AJ, Hudson BD, Sergeev E, Molloy C, et al. Chemogenetics defines receptor-mediated functions of short chain free fatty acids. Nat Chem Biol. 2019;15:489-98.

76. Li Z, Yi C-X, Katiraei S, Kooijman S, Zhou E, Chung CK, et al. Butyrate reduces appetite and activates brown adipose tissue via the gut-brain neural circuit. Gut. 2018;67:1269-79.

77. Kimura I, Ozawa K, Inoue D, Imamura T, Kimura K, Maeda T, et al. The gut microbiota suppresses insulin-mediated fat accumulation via the short-chain fatty acid receptor GPR43. Nat Commun. 2013:4:1829.

78. Iwasaki Y, Sendo M, Dezaki K, Hira T, Sato T, Nakata M, et al. GLP-1 release and vagal afferent activation mediate the beneficial metabolic and chronotherapeutic effects of D-allulose. Nat Commun. 2018;9:113.

79. Song Y, Koehler JA, Baggio LL, Powers AC, Sandoval DA, Drucker DJ. Gutproglucagon-derived peptides are essential for regulating glucose homeostasis in mice. Cell Metab. 2019;30:976-986.e3.

80. Gero D, Steinert RE, Hosa H, Cummings DE, Bueter M. Appetite, glycemia, and entero-insular hormone responses differ between oral, gastric-remnant, and duodenal administration of a mixed-meal test after Roux-en-Y gastric bypass. Diabetes Care. 2018;41:1295-8.

81. Lu VB, Rievaj J, O'Flaherty EA, Smith CA, Pais R, Pattison LA, et al. Adenosine triphosphate is co-secreted with glucagon-like peptide-1 to modulate intestinal enterocytes and afferent neurons. Nat Commun. 2019;10:1029.

82. Rangwala SM, D'Aquino K, Zhang YM, Bader L, Edwards W, Zheng S, et al. A long-acting PYY(3-36) analog mediates robust anorectic efficacy with minimal emesis in nonhuman primates. Cell Metab. 2019;29:837-843.e5.

83. Lerche S, Brock B, Rungby J, Bøtker HE, Møller N, Rodell A, et al. Glucagonlike peptide-1 inhibits blood-brain glucose transfer in humans. Diabetes. 2008:57:325-31.

84. Sam AH, Gunner DJ, King A, Persaud SJ, Brooks L, Hostomska K, et al. Selective ablation of peptide YY cells in adult mice reveals their role in beta cell survival. Gastroenterology. 2012;143:459-68.

85. Schirra J, Nicolaus M, Roggel R, Katschinski M, Storr M, Woerle HJ, et al. Endogenous glucagon-like peptide 1 controls endocrine pancreatic secretion and antro-pyloro-duodenal motility in humans. Gut. 2006:55:243-51.

86. Hagve M, Gjessing PF, Hole MJ, Jansen KM, Fuskevag OM, Mollnes TE, et al. Perioperative infusion of glucagon like peptide-1 prevents insulin resistance after surgical trauma in female pigs. Endocrinology. 2019;160:2892-902.

87. Cox HM, Tough IR, Woolston AM, Zhang L, Nguyen AD, Sainsbury A, et al. Peptide YY is critical for acylethanolamine receptor Gpr119induced activation of gastrointestinal mucosal responses. Cell Metab. 2010;11:532-42

88. Byrne CS, Chambers ES, Alhabeeb H, Chhina N, Morrison DJ, Preston T, et al. Increased colonic propionate reduces anticipatory reward responses in the human striatum to high-energy foods. Am J Clin Nutr. 2016;104:5-14.

89. Frost G, Sleeth ML, Sahuri-Arisoylu M, Lizarbe B, Cerdan S, Brody L, et al. The short-chain fatty acid acetate reduces appetite via a central homeostatic mechanism. Nat Commun. 2014:5:3611.

90. Jesus P, Ouelaa W, Francois M, Riachy L, Guerin C, Aziz M, et al. Alteration of intestinal barrier function during activity-based anorexia in mice. Clin Nutr. 2014;33:1046-53.

91. Mörkl S, Lackner S, Meinitzer A, Mangge H, Lehofer M, Halwachs B, et al. Gut microbiota, dietary intakes and intestinal permeability reflected by serum zonulin in women. Eur J Nutr. 2018:57:2985-97.

92. Schroeder M, Jakovcevski M, Polacheck T, Drori $Y$, Luoni A, Roh S, et al. Placental miR-340 mediates vulnerability to activity based anorexia in mice. Nat Commun. 2018:9:1596.

93. Cani PD, Possemiers S, Van de Wiele T, Guiot Y, Everard A, Rottier O, et al. Changes in gut microbiota control inflammation in obese mice through a mechanism involving GLP-2-driven improvement of gut permeability. Gut. 2009:58:1091-103.

94. Cani PD, Osto M, Geurts L and Everard A. Involvement of gut microbiota in the development of low-grade inflammation and type 2 diabetes associated with obesity. Gut Microbes. 2012;3:279-88

95. Everard A, Lazarevic V Derrien M, Girard M, Muccioli GG, Muccioli GM et al. Responses of gut microbiota and glucose and lipid metabolism to 
prebiotics in genetic obese and diet-induced leptin-resistant mice. Diabetes. 2011;60:2775-86

96. Dominique M, Legrand R, Galmiche M, Azhar S, Deroissart C, Guérin C, et al. Changes in Microbiota and Bacterial Protein Caseinolytic Peptidase B During Food Restriction in Mice: Relevance for the Onset and Perpetuation of Anorexia Nervosa. Nutrients. 2019;11:2514

97. Cryan JF, O'Riordan KJ, Cowan CSM, Sandhu KV, Bastiaanssen TFS, Boehme M, et al. The Microbiota-Gut-Brain Axis. Physiol Rev. 2019;99:1877-2013.

98. Cao J, Peng J, An H, He Q, Boronina T, Guo S, et al. Endotoxemia-mediated activation of acetyltransferase P300 impairs insulin signaling in obesity. Nat Commun. 2017;8:131.

99. Anitha M, Vijay-Kumar M, Sitaraman SV, Gewirtz AT and Srinivasan S. Gut microbial products regulate murine gastrointestinal motility via Toll-like receptor 4 signaling. Gastroenterology. 2012;143:1006-16.e4.

100. Jing Y, Yu Y, Bai F, Wang L, Yang D, Zhang C, et al. Effect of fecal microbiota transplantation on neurological restoration in a spinal cord injury mouse model: involvement of brain-gut axis. Microbiome. 2021;9:59.

101. Wanders AJ, van den Borne JJ, de Graaf C, Hulshof T, Jonathan MC, Kristensen $\mathrm{M}$, et al. Effects of dietary fibre on subjective appetite, energy intake and body weight: a systematic review of randomized controlled trials. Obes Rev. 2011;12:724-39.

102. Serena C, Ceperuelo-Mallafré V, Keiran N, Queipo-Ortuño MI, Bernal R, Gomez-Huelgas R, et al. Elevated circulating levels of succinate in human obesity are linked to specific gut microbiota. Isme j. 2018;12:1642-57.

103. De Vadder F, Kovatcheva-Datchary P, Zitoun C, Duchampt A, Bäckhed F, Mithieux G. Microbiota-produced succinate improves glucose homeostasis via intestinal gluconeogenesis. Cell Metab. 2016;24:151-7.

104. Mills EL, Pierce KA, Jedrychowski MP, Garrity R, Winther S, Vidoni S, et al. Accumulation of succinate controls activation of adipose tissue thermogenesis. Nature. 2018;560:102-6.

105. Wang K, Liao M, Zhou N, Bao L, Ma K, Zheng Z, et al. Parabacteroides distasonis alleviates obesity and metabolic dysfunctions via production of succinate and secondary bile acids. Cell Rep. 2019;26:222-235.e5.

106. Mithieux G. A novel function of intestinal gluconeogenesis: central signaling in glucose and energy homeostasis. Nutrition. 2009;25:881-4.

107. Soto M, Herzog C, Pacheco JA, Fujisaka S, Bullock K, Clish CB, et al. Gut microbiota modulate neurobehavior through changes in brain insulin sensitivity and metabolism. Mol Psychiatry. 2018;23:2287-301.

108. Israelyan N, Del Colle A, Li Z, Park Y, Xing A, Jacobsen JPR, et al. Effects of serotonin and slow-release 5-hydroxytryptophan on gastrointestinal motility in a mouse model of depression. Gastroenterology. 2019;157:507-521.e4.

109. Clarke G, Grenham S, Scully P, Fitzgerald P, Moloney RD, Shanahan F, et al. The microbiome-gut-brain axis during early life regulates the hippocampal serotonergic system in a sex-dependent manner. Mol Psychiatry. 2013;18:666-73.

110. Bhattarai Y, Williams BB, Battaglioli EJ, Whitaker WR, Till L, Grover M, et al. Gut microbiota-produced tryptamine activates an epithelial G-protein-coupled receptor to increase colonic secretion. Cell Host Microbe. 2018;23:775-785.e5.

111. Gartner SN, Aidney F, Klockars A, Prosser C, Carpenter EA, Isgrove K, et al. Intragastric preloads of I-tryptophan reduce ingestive behavior via oxytocinergic neural mechanisms in male mice. Appetite. 2018;125:278-86.

112. Miao J, Adewole D, Liu S, Xi P, Yang C, Yin Y. Tryptophan supplementation increases reproduction performance, milk yield, and milk composition in lactating sows and growth performance of their piglets. J Agric Food Chem. 2019;67:5096-104.

113. Zhao Y, Wu XY, Xu SX, Xie JY, Xiang KW, Feng L, et al. Dietary tryptophan affects growth performance, digestive and absorptive enzyme activities, intestinal antioxidant capacity, and appetite and GH-IGF axis-related gene expression of hybrid catfish (Pelteobagrus vachellifemale symbol $x$ Leiocassis longirostrismale symbol). Fish Physiol Biochem. 2019:45:1627-47.

114. Ullrich SS, Fitzgerald PCE, Giesbertz P, Steinert RE, Horowitz M, Feinle-Bisset C. Effects of intragastric administration of tryptophan on the blood glucose response to a nutrient drink and energy intake, in Lean and Obese Men. Nutrients. 2018;10:463.

115. Steinert RE, Luscombe-Marsh ND, Little TJ, Standfield S, Otto B, Horowitz M, et al. Effects of intraduodenal infusion of L-tryptophan on ad libitum eating, antropyloroduodenal motility, glycemia, insulinemia, and gut peptide secretion in healthy men. J Clin Endocrinol Metab. 2014;99:3275-84.

116. McVeay C, Fitzgerald PCE, Ullrich SS, Steinert RE, Horowitz M, Feinle-Bisset C. Effects of intraduodenal administration of lauric acid and L-tryptophan, alone and combined, on gut hormones, pyloric pressures, and energy intake in healthy men. Am J Clin Nutr. 2019;109:1335-43.
117. Ayaso R, Ghattas H, Abiad M, Obeid O. Meal pattern of male rats maintained on amino acid supplemented diets: the effect of tryptophan, lysine, arginine, proline and threonine. Nutrients. 2014;6:2509-22.

118. Zapata RC, Singh A, Ajdari NM, Chelikani PK. Dietary tryptophan restriction dose-dependently modulates energy balance, gut hormones, and microbiota in obesity-prone rats. Obesity (Silver Spring). 2018;26:730-9.

119. Dodd D, Spitzer MH, Van Treuren W, Merrill BD, Hryckowian AJ, Higginbottom SK, et al. A gut bacterial pathway metabolizes aromatic amino acids into nine circulating metabolites. Nature. 2017;551:648-52.

120. Devlin AS, Marcobal A, Dodd D, Nayfach S, Plummer N, Meyer T, et al. Modulation of a circulating uremic solute via rational genetic manipulation of the gut microbiota. Cell Host Microbe. 2016;20:709-15.

121. Chimerel C, Emery E, Summers DK, Keyser U, Gribble FM, Reimann F. Bacterial metabolite indole modulates incretin secretion from intestinal enteroendocrine $L$ cells. Cell Rep. 2014;9:1202-8.

122. Scott SA, Fu J, Chang PV. Microbial tryptophan metabolites regulate gut barrier function via the aryl hydrocarbon receptor. Proc Natl Acad Sci U S A. 2020;117:19376-87.

123. Wu Q, Clark MS, Palmiter RD. Deciphering a neuronal circuit that mediates appetite. Nature. 2012;483:594-7.

124. Capello AE, Markus CR. Effect of sub chronic tryptophan supplementation on stress-induced cortisol and appetite in subjects differing in 5-HTTLPR genotype and trait neuroticism. Psychoneuroendocrinology. 2014;45:96-107.

125. De Vadder F, Grasset E, Mannerås Holm L, Karsenty G, Macpherson AJ, Olofsson LE, et al. Gut microbiota regulates maturation of the adult enteric nervous system via enteric serotonin networks. Proc Natl Acad Sci U S A. 2018;115:6458-63.

126. Yano JM, Yu K, Donaldson GP, Shastri GG, Ann P, Ma L, et al. Indigenous bacteria from the gut microbiota regulate host serotonin biosynthesis. Cell. 2015;161:264-76.

127. Reigstad CS, Salmonson CE, Rainey JF 3rd, Szurszewski JH, Linden DR, Sonnenburg JL, et al. Gut microbes promote colonic serotonin production through an effect of short-chain fatty acids on enterochromaffin cells. FASEB J. 2015;29:1395-403.

128. Martin AM, Lumsden AL, Young RL, Jessup CF, Spencer NJ, Keating DJ. Regional differences in nutrient-induced secretion of gut serotonin. Physiol Rep. 2017;5:e13199.

129. Ye L, Bae M, Cassilly CD, Jabba SV, Thorpe DW, Martin AM, et al. Enteroendocrine cells sense bacterial tryptophan catabolites to activate enteric and vagal neuronal pathways. Cell Host Microbe. 2021;29:179-196.e9.

130. Williams BB, Van Benschoten AH, Cimermancic P, Donia MS, Zimmermann $M$, Taketani $M$, et al. Discovery and characterization of gut microbiota decarboxylases that can produce the neurotransmitter tryptamine. Cell Host Microbe. 2014;16:495-503.

131. Kopeikina E, Dukhinova M, Yung AWY, Veremeyko T, Kuznetsova IS, Lau TYB, et al. Platelets promote epileptic seizures by modulating brain serotonin level, enhancing neuronal electric activity, and contributing to neuroinflammation and oxidative stress. Prog Neurobiol. 2020;188:101783.

132. Nectow AR, Schneeberger M, Zhang H, Field BC, Renier N, Azevedo E, et al. Identification of a brainstem circuit controlling feeding. Cell. 2017;170:42942 e11.

133. van Lingen M, Sidorova M, Alenina N, Klempin F. Lack of brain serotonin affects feeding and differentiation of newborn cells in the adult hypothalamus. Front Cell Dev Biol. 2019;7:65.

134. D'Agostino G, Lyons D, Cristiano C, Lettieri M, Olarte-Sanchez C, Burke LK, et al. Nucleus of the solitary tract serotonin $5-\mathrm{HT} 2 \mathrm{C}$ receptors modulate food intake. Cell Metab. 2018;28:619-30 e5.

135. Crane JD, Palanivel R, Mottillo EP, Bujak AL, Wang H, Ford RJ, et al. Inhibiting peripheral serotonin synthesis reduces obesity and metabolic dysfunction by promoting brown adipose tissue thermogenesis. Nat Med. 2015;21:16672.

136. Savastano DM, Covasa M. Intestinal nutrients elicit satiation through concomitant activation of CCK(1) and 5-HT(3) receptors. Physiol Behav. 2007:92:434-42.

137. Janssen P, Vos R, Van Oudenhove L, Tack J. Influence of the 5-HT3 receptor antagonist ondansetron on gastric sensorimotor function and nutrient tolerance in healthy volunteers. Neurogastroenterol Motil. 2011;23:444-9 e175.

138. Rhoades JL, Nelson JC, Nwabudike I, Yu SK, McLachlan IG, Madan GK, et al. ASICs mediate food responses in an enteric serotonergic neuron that controls foraging behaviors. Cell. 2019;176:85-97.e14. 
139. Heisler LK, Jobst EE, Sutton GM, Zhou L, Borok E, Thornton-Jones Z, et al. Serotonin reciprocally regulates melanocortin neurons to modulate food intake. Neuron. 2006;51:239-49.

140. Valles-Colomer M, Falony G, Darzi Y, Tigchelaar EF, Wang J, Tito RY, et al. The neuroactive potential of the human gut microbiota in quality of life and depression. Nat Microbiol. 2019:4:623-32.

141. Yunes RA, Poluektova EU, Dyachkova MS, Klimina KM, Kovtun AS, Averina $\mathrm{OV}$, et al. GABA production and structure of gadB/gadC genes in Lactobacillus and Bifidobacterium strains from human microbiota. Anaerobe. 2016;42:197-204.

142. Barrett E, Ross RP, O'Toole PW, Fitzgerald GF, Stanton C. gammaAminobutyric acid production by culturable bacteria from the human intestine. J Appl Microbiol. 2012;113:411-7.

143. Liu R, Hong J, Xu X, Feng Q, Zhang D, Gu Y, et al. Gut microbiome and serum metabolome alterations in obesity and after weight-loss intervention. Nat Med. 2017;23:859-68

144. Matsumoto M, Ooga T, Kibe R, Aiba Y, Koga Y and Benno Y. Colonic Absorption of Low-Molecular-Weight Metabolites Influenced by the Intestinal Microbiome: A Pilot Study. PLoS One. 2017;12:e0169207.

145. Fujisaka S, Avila-Pacheco J, Soto M, Kostic A, Dreyfuss JM, Pan H, et al. Diet, Genetics, and the Gut Microbiome Drive Dynamic Changes in Plasma Metabolites. Cell Rep. 2018;22:3072-86.

146. Kootte RS, Levin E, Salojarvi J, Smits LP, Hartstra AV, Udayappan SD, et al. Improvement of Insulin Sensitivity after Lean Donor Feces in Metabolic Syndrome Is Driven by Baseline Intestinal Microbiota Composition. Cell Metab. 2017;26:611-619 e6.

147. Xu J, Bartolome CL, Low CS, Yi X, Chien C-H, Wang P, et al. Genetic identification of leptin neural circuits in energy and glucose homeostases. Nature. 2018;556:505-9.

148. Kim ER, Wu Z, Sun $H, X u Y$, Mangieri LR, Xu Y, et al. Hypothalamic nonAgRP, non-POMC GABAergic neurons are required for postweaning feeding and NPY hyperphagia. J Neurosci. 2015;35:10440-50.

149. Auteri M, Zizzo MG, Serio R. GABA and GABA receptors in the gastrointestinal tract: from motility to inflammation. Pharmacol Res. 2015;93:11-21.

150. Krashes MJ, Shah BP, Koda S, Lowell BB. Rapid versus delayed stimulation of feeding by the endogenously released AgRP neuron mediators GABA, NPY, and AgRP. Cell Metab. 2013;18:588-95.

151. Engström Ruud L, Pereira MMA, de Solis AJ, Fenselau H, Brüning JC. NPY mediates the rapid feeding and glucose metabolism regulatory functions of AgRP neurons. Nat Commun. 2020;11:442.

152. Takanaga H, Ohtsuki S, Hosoya K, Terasaki T. GAT2/BGT-1 as a system responsible for the transport of gamma-aminobutyric acid at the mouse blood-brain barrier. J Cereb Blood Flow Metab. 2001;21:1232-9.

153. Knudsen GM, Poulsen HE, Paulson OB. Blood-brain barrier permeability in galactosamine-induced hepatic encephalopathy. No evidence for increased GABA-transport. J Hepatol. 1988;6:187-92.

154. Constans C, Ahnine H, Santin M, Lehericy S, Tanter M, Pouget P, et al. Noninvasive ultrasonic modulation of visual evoked response by GABA delivery through the blood brain barrier. J Control Release. 2020;318:223-31.

155. Wang DM, Chacher B, Liu HY, Wang JK, Lin J, Liu JX. Effects of gammaaminobutyric acid on feed intake, growth performance and expression of related genes in growing lambs. Animal. 2015;9:445-8.

156. Wang DM, Liu HY, Wang C, Liu JX, Ferguson JD. Effects of rumen-protected gamma-aminobutyric acid on feed intake, performance and antioxidative status in transition cows. Livestock Science. 2013;153:66-72.

157. Sobrido-Cameán D, Yáñez-Guerra LA, Robledo D, López-Varela E, Rodicio MC, Elphick MR, et al. Cholecystokinin in the central nervous system of the sea lamprey Petromyzon marinus: precursor identification and neuroanatomical relationships with other neuronal signalling systems. Brain Struct Funct. 2020;225:249-84.

158. Pedersen HK, Gudmundsdottir V, Nielsen HB, Hyotylainen T, Nielsen T, Jensen BA, et al. Human gut microbes impact host serum metabolome and insulin sensitivity. Nature. 2016;535:376-81.

159. Ottosson F, Brunkwall L, Ericson U, Nilsson PM, Almgren P, Fernandez C, et al. Connection between BMl-related plasma metabolite profile and gut microbiota. J Clin Endocrinol Metab. 2018;103:1491-501.

160. Wang TJ, Larson MG, Vasan RS, Cheng S, Rhee EP, McCabe E, et al. Metabolite profiles and the risk of developing diabetes. Nat Med. 2011;17:448-53.

161. Ridaura VK, Faith JJ, Rey FE, Cheng J, Duncan AE, Kau AL, et al. Gut microbiota from twins discordant for obesity modulate metabolism in mice. Science. 2013;341:1241214.
162. White PJ, Newgard CB. Branched-chain amino acids in disease. Science. 2019;363:582-3

163. Zeng SL, Li SZ, Xiao PT, Cai YY, Chu C, Chen BZ, et al. Citrus polymethoxyflavones attenuate metabolic syndrome by regulating gut microbiome and amino acid metabolism. Sci Adv. 2020;6:eaax6208.

164. Karusheva Y, Koessler T, Strassburger K, Markgraf D, Mastrototaro L, Jelenik T, et al. Short-term dietary reduction of branched-chain amino acids reduces meal-induced insulin secretion and modifies microbiome composition in type 2 diabetes: a randomized controlled crossover trial. Am J Clin Nutr. 2019;110:1098-107.

165. Newgard CB, An J, Bain JR, Muehlbauer MJ, Stevens RD, Lien LF, et al. A branched-chain amino acid-related metabolic signature that differentiates obese and lean humans and contributes to insulin resistance. Cell Metab. 2009;9:311-26.

166. Solon-Biet SM, Cogger VC, Pulpitel T, Wahl D, Clark X, Bagley E, et al. Branched chain amino acids impact health and lifespan indirectly via amino acid balance and appetite control. Nat Metab. 2019;1:532-45.

167. Yin J, Ma J, Li Y, Ma X, Chen J, Zhang H, et al. Branched-chain amino acids, especially of leucine and valine, mediate the protein restricted response in a piglet model. Food Funct. 2020;11:1304-11.

168. Tian M, Heng J, Song H, Shi K, Lin X, Chen F, et al. Dietary branched-chain amino acids regulate food intake partly through intestinal and hypothalamic amino acid receptors in piglets. J Agric Food Chem. 2019;67:6809-18.

169. Just S, Mondot S, Ecker J, Wegner K, Rath E, Gau L, et al. The gut microbiota drives the impact of bile acids and fat source in diet on mouse metabolism. Microbiome. 2018;6:134.

170. Sayin SI, Wahlstrom A, Felin J, Jantti S, Marschall HU, Bamberg K, et al. Gut microbiota regulates bile acid metabolism by reducing the levels of taurobeta-muricholic acid, a naturally occurring FXR antagonist. Cell Metab. 2013; 17:225-35.

171. Wang X, Yang S, Li S, Zhao L, Hao Y, Qin J, et al. Aberrant gut microbiota alters host metabolome and impacts renal failure in humans and rodents. Gut. 2020:69:2131-42

172. Ghosh TS, Rampelli S, Jeffery IB, Santoro A, Neto M, Capri M, et al. Mediterranean diet intervention alters the gut microbiome in older people reducing frailty and improving health status: the NU-AGE 1-year dietary intervention across five European countries. Gut. 2020:69:1218-28.

173. Krautkramer KA, Fan J, Bäckhed F. Gut microbial metabolites as multikingdom intermediates. Nat Rev Microbiol. 2021;19:77-94.

174. de Aguiar Vallim TQ, Tarling EJ, Edwards PA. Pleiotropic roles of bile acids in metabolism. Cell Metab. 2013;17:657-69.

175. Higuchi S, Ahmad TR, Argueta DA, Perez PA, Zhao C, Schwartz GJ, et al. Bile acid composition regulates GPR119-dependent intestinal lipid sensing and food intake regulation in mice. Gut. 2020;69:1620-8.

176. Kuhre RE, Wewer Albrechtsen NJ, Larsen O, Jepsen SL, Balk-Moller E, Andersen DB, et al. Bile acids are important direct and indirect regulators of the secretion of appetite- and metabolism-regulating hormones from the gut and pancreas. Mol Metab. 2018;11:84-95.

177. Fetissov SO, Hamze Sinno M, Coeffier M, Bole-Feysot C, Ducrotte P, Hokfelt $\mathrm{T}$, et al. Autoantibodies against appetite-regulating peptide hormones and neuropeptides: putative modulation by gut microflora. Nutrition. 2008;24: 348-59.

178. Arnoriaga-Rodríguez M, Mayneris-Perxachs J, Burokas A, Pérez-Brocal V, Moya A, Portero-Otin M, et al. Gut bacterial ClpB-like gene function is associated with decreased body weight and a characteristic microbiota profile. Microbiome. 2020;8:59.

179. Dominique M, Legrand R, Galmiche M, Azhar S, Deroissart C, Guérin C, et al. Changes in microbiota and bacterial protein caseinolytic peptidase $B$ during food restriction in mice: relevance for the onset and perpetuation of anorexia nervosa. Nutrients. 2019;11:2514

180. Fetissov SO, Hamze Sinno M, Coquerel Q, Do Rego JC, Coëffier M, Gilbert D, et al. Emerging role of autoantibodies against appetite-regulating neuropeptides in eating disorders. Nutrition. 2008;24:854-9.

181. Fetissov SO, Hokfelt T. On the origin of eating disorders: altered signaling between gut microbiota, adaptive immunity and the brain melanocortin system regulating feeding behavior. Curr Opin Pharmacol. 2019;48:82-91.

182. Bouhajja H, Bougacha-Elleuch N, Lucas N, Legrand R, Marrakchi R, Kaveri SV, et al. Affinity kinetics of leptin-reactive immunoglobulins are associated with plasma leptin and markers of obesity and diabetes. Nutr Diabetes. 2018:8:32.

183. Takagi K, Legrand R, Asakawa A, Amitani H, Francois M, Tennoune N, et al. Anti-ghrelin immunoglobulins modulate ghrelin stability and its orexigenic effect in obese mice and humans. Nat Commun. 2013;4:2685. 
184. Coquerel Q, Sinno MH, Boukhettala N, Coeffier M, Terashi M, Bole-Feysot C et al. Intestinal inflammation influences alpha-MSH reactive autoantibodies: relevance to food intake and body weight. Psychoneuroendocrinology. 2012;37:94-106

185. Fetissov SO, Harro J, Jaanisk M, Jarv A, Podar I, Allik J, et al. Autoantibodies against neuropeptides are associated with psychological traits in eating disorders. Proc Natl Acad Sci U S A. 2005;102:14865-70.

186. Lucas N, Legrand R, Bole-Feysot C, Breton J, Coeffier M, Akkermann K, et al. Immunoglobulin $\mathrm{G}$ modulation of the melanocortin 4 receptor signaling in obesity and eating disorders. Transl Psychiatry. 2019;9:87.

187. Chagwedera DN, Ang QY, Bisanz JE, Leong YA, Ganeshan K, Cai J, et al. Nutrient sensing in CD11c cells alters the gut microbiota to regulate food intake and body mass. Cell Metab. 2019;30:364-73 e7.

188. Yue JT, Lam TK. Antiobesogenic effects of central GIPR antagonism. J Clin Invest. 2019:129:3532-5.

189. Bravo-San Pedro JM, Sica V, Martins I, Pol J, Loos F, Maiuri MC, et al. AcylCoA-binding protein is a lipogenic factor that triggers food intake and obesity. Cell Metab. 2019;30:754-767.e9.

190. Wang Y, Kim J, Schmit MB, Cho TS, Fang C, Cai H. A bed nucleus of stria terminalis microcircuit regulating inflammation-associated modulation of feeding. Nat Commun. 2019;10:2769.

191. Mitchison D, Mond J, Bussey K, Griffiths S, Trompeter N, Lonergan A, et al. DSM-5 full syndrome, other specified, and unspecified eating disorders in Australian adolescents: prevalence and clinical significance. Psychol Med. 2020;50:981-90.

192. Robinette TM, Nicholatos JW, Francisco AB, Brooks KE, Diao RY, Sorbi S, et al. SIRT1 accelerates the progression of activity-based anorexia. Nat Commun. 2020;11:2814

193. Sild M and Booij L. Histone deacetylase 4 (HDAC4): a new player in anorexia nervosa? Mol Psychiatry. 2019;24:1425-34.

194. Udo T and Grilo CM. Prevalence and Correlates of DSM-5-Defined Eating Disorders in a Nationally Representative Sample of U.S. Adults. Biol Psychiatry. 2018;84:345-54.

195. Scheuing N, Bartus B, Berger G, Haberland H, Icks A, Knauth B, et al. Clinical characteristics and outcome of 467 patients with a clinically recognized eating disorder identified among 52,215 patients with type 1 diabetes: a multicenter german/austrian study. Diabetes Care. 2014;37:1581-9.

196. Tith RM, Paradis G, Potter BJ, Low N, Healy-Profitós J, He S, et al. Association of Bulimia Nervosa With Long-term Risk of Cardiovascular Disease and Mortality Among Women. JAMA Psychiatry. 2019;77:44-51.

197. Gonzalez-Santana A and Diaz Heijtz R. Bacterial Peptidoglycans from Microbiota in Neurodevelopment and Behavior. Trends Mol Med. 2020;26: 729-43.

198. Al-Najim W, Docherty NG and le Roux CW. Food Intake and Eating Behavior After Bariatric Surgery. Physiol Rev. 2018;98:1113-41.

199. Davidson GL, Raulo A and Knowles SCL. Identifying Microbiome-Mediated Behaviour in Wild Vertebrates. Trends Ecol Evol. 2020:35:972-980.

200. Muller PA, Schneeberger M, Matheis F, Wang P, Kerner Z, llanges A, et al. Microbiota modulate sympathetic neurons via a gut-brain circuit. Nature. 2020;583:441-6.

201. O'Donnell MP, Fox BW, Chao PH, Schroeder FC and Sengupta P. A neurotransmitter produced by gut bacteria modulates host sensory behaviour. Nature. 2020:583:415-20.

202. Yin J, Li Y, Han H, Chen S, Gao J, Liu G, et al. Melatonin reprogramming of gut microbiota improves lipid dysmetabolism in high-fat diet-fed mice. J Pineal Res. 2018;65:e12524.

203. Wu TR, Lin CS, Chang CJ, Lin TL, Martel J, Ko YF, et al. Gut commensal Parabacteroides goldsteinii plays a predominant role in the anti-obesity effects of polysaccharides isolated from Hirsutella sinensis. Gut. 2019;68:248-62.

204. Zhang Y, Huang R, Cheng M, Wang L, Chao J, Li J, et al. Gut microbiota from NLRP3-deficient mice ameliorates depressive-like behaviors by regulating astrocyte dysfunction via circHIPK2. Microbiome. 2019;7:116

205. Medina-Rodriguez EM, Madorma D, O'Connor G, Mason BL, Han D, Deo SK, et al. Identification of a Signaling Mechanism by Which the Microbiome Regulates Th17 Cell-Mediated Depressive-Like Behaviors in Mice. Am J Psychiatry. 2020;177:974-90.

206. Jiang L, Lang S, Duan Y, Zhang X, Gao B, Chopyk J, et al. Intestinal virome in patients with alcoholic hepatitis. Hepatology. 2020;72:2182-96.

207. Rasmussen TS, Mentzel CMJ, Kot W, Castro-Mejía JL, Zuffa S, Swann JR, et al. Faecal virome transplantation decreases symptoms of type 2 diabetes and obesity in a murine model. Gut. 2020;69:2122-2130.
208. Plovier H, Everard A, Druart C, Depommier C, Van Hul M, Geurts L, et al. A purified membrane protein from Akkermansia muciniphila or the pasteurized bacterium improves metabolism in obese and diabetic mice. Nat Med. 2017:23:107-13.

209. Dewulf EM, Cani PD, Claus SP, Fuentes S, Puylaert PG, Neyrinck AM, et al. Insight into the prebiotic concept: lessons from an exploratory, double blind intervention study with inulin-type fructans in obese women. Gut. 2013;62:1112-21.

210. Rodriguez J, Hiel S, Neyrinck AM, Le Roy T, Pötgens SA, Leyrolle Q, et al. Discovery of the gut microbial signature driving the efficacy of prebiotic intervention in obese patients. Gut. 2020;69:1975-87.

211. Cabral LQT, Ximenez JA, Moreno KGT and Fernandes R. Probiotics have minimal effects on appetite-related hormones in overweight or obese individuals: A systematic review of randomized controlled trials. Clin Nutr. 2020:40:1776-87

212. O'Toole PW, Marchesi JR and Hill C. Next-generation probiotics: the spectrum from probiotics to live biotherapeutics. Nat Microbiol. 2017:2:17057.

213. Everard A, Belzer C, Geurts L, Ouwerkerk JP, Druart C, Bindels LB, et al. Crosstalk between Akkermansia muciniphila and intestinal epithelium controls diet-induced obesity. Proc Natl Acad Sci U S A. 2013;110:9066-71.

214. Everard A, Lazarevic V, Derrien M, Girard M, Muccioli GG, Neyrinck AM, et al. Responses of gut microbiota and glucose and lipid metabolism to prebiotics in genetic obese and diet-induced leptin-resistant mice. Diabetes 2011;60:2775-86

215. Payahoo L, Khajebishak Y, Alivand MR, Soleimanzade H, Alipour S, Barzegari $A$, et al. Investigation the effect of oleoylethanolamide supplementation on the abundance of Akkermansia muciniphila bacterium and the dietary intakes in people with obesity: A randomized clinical trial. Appetite. 2019; 141:104301

216. Modasia A, Parker A, Jones E, Stentz R, Brion A, Goldson A, et al. Regulation of Enteroendocrine Cell Networks by the Major Human Gut Symbiont Bacteroides thetaiotaomicron. Front Microbiol. 2020;11:575595.

217. Hata T, Miyata N, Takakura S, Yoshihara K, Asano Y, Kimura-Todani T, et al. The Gut Microbiome Derived From Anorexia Nervosa Patients Impairs Weight Gain and Behavioral Performance in Female Mice. Endocrinology. 2019:160:2441-52.

218. Holscher HD. Dietary fiber and prebiotics and the gastrointestinal microbiota. Gut Microbes. 2017:8:172-84.

219. Ortega-Vega EL, Guzmán-Castañeda SJ, Campo O, Velásquez-Mejía EP, de la Cuesta-Zuluaga J, Bedoya $\mathrm{G}$, et al. Variants in genes of innate immunity, appetite control and energy metabolism are associated with host cardiometabolic health and gut microbiota composition. Gut Microbes. 2020;11:556-68

220. Bjerg AT, Kristensen M, Ritz C, Holst JJ, Rasmussen C, Leser TD, et al. Lactobacillus paracasei subsp paracasei L. casei W8 suppresses energy intake acutely. Appetite. 2014;82:111-8.

221. Narmaki E, Borazjani M, Ataie-Jafari A, Hariri N, Doost AH, Qorbani M, et al. The combined effects of probiotics and restricted calorie diet on the anthropometric indices, eating behavior, and hormone levels of obese women with food addiction: a randomized clinical trial. Nutr Neurosci. 2020 https://doi.org/10.1080/1028415X.2020.1826763.

222. Jiang J, Qi L, Lv Z, Wei Q and Shi F. Dietary stevioside supplementation increases feed intake by altering the hypothalamic transcriptome profile and gut microbiota in broiler chickens. J Sci Food Agric. 2021;101:2156-67.

223. Legrand R, Lucas N, Dominique M, Azhar S, Deroissart C, Le Solliec MA, et al Commensal Hafnia alvei strain reduces food intake and fat mass in obese mice-a new potential probiotic for appetite and body weight management. Int J Obes (Lond). 2020:44:1041-51.

224. Saito H, Nakakita Y, Segawa S and Tsuchiya Y. Oral administration of heat-killed Lactobacillus brevis SBC8803 elevates the ratio of acyl/des-acyl ghrelin in blood and increases short-term food intake. Benef Microbes. 2019;10:671-7.

225. Lai HH, Chiu CH, Kong MS, Chang CJ and Chen CC. Probiotic Lactobacillus casei: Effective for Managing Childhood Diarrhea by Altering Gut Microbiota and Attenuating Fecal Inflammatory Markers. Nutrients. 2019;11:1150.

226. Gioacchini G, Ciani E, Pessina A, Cecchini C, Silvi S, Rodiles A, et al. Effects of Lactogen 13, a New Probiotic Preparation, on Gut Microbiota and Endocrine Signals Controlling Growth and Appetite of Oreochromis niloticus Juveniles. Microb Ecol. 2018:76:1063-74.

227. Bagarolli RA, Tobar N, Oliveira AG, Araújo TG, Carvalho BM, Rocha GZ, et al. Probiotics modulate gut microbiota and improve insulin sensitivity in DIO mice. J Nutr Biochem. 2017;50:16-25. 
228. Sanchez M, Darimont C, Panahi S, Drapeau V, Marette A, Taylor VH, et al. Effects of a Diet-Based Weight-Reducing Program with Probiotic Supplementation on Satiety Efficiency, Eating Behaviour Traits, and Psychosocial Behaviours in Obese Individuals. Nutrients. 2017:9:284.

229. Falcinelli S, Rodiles A, Unniappan S, Picchietti S, Gioacchini G, Merrifield DL, et al. Probiotic treatment reduces appetite and glucose level in the zebrafish model. Sci Rep. 2016;6:18061.

230. Reimer RA, Willis HJ, Tunnicliffe JM, Park H, Madsen KL and Soto-Vaca A. Inulin-type fructans and whey protein both modulate appetite but only fructans alter gut microbiota in adults with overweight/obesity: A randomized controlled trial. Mol Nutr Food Res. 2017;61. https://doi.org/10.1 002/mnfr.201700484.

231. Fouré $M$, Dugardin C, Foligné $B$, Hance $P$, Cadalen T, Delcourt $A$, et al. Chicory Roots for Prebiotics and Appetite Regulation: A Pilot Study in Mice. J Agric Food Chem. 2018;66:6439-49.

232. Yan S, Shi R, Li L, Ma S, Zhang H, Ye J, et al. Mannan Oligosaccharide Suppresses Lipid Accumulation and Appetite in Western-Diet-Induced Obese Mice Via Reshaping Gut Microbiome and Enhancing Short-Chain Fatty Acids Production. Mol Nutr Food Res. 2019;63:e1900521.

233. Hira T, Suto R, Kishimoto Y, Kanahori S and Hara H. Resistant maltodextrin or fructooligosaccharides promotes GLP-1 production in male rats fed a highfat and high-sucrose diet, and partially reduces energy intake and adiposity. Eur J Nutr. 2018;57:965-79.

234. Javdan B, Lopez JG, Chankhamjon P, Lee YJ, Hull R, Wu Q, et al. Personalized Mapping of Drug Metabolism by the Human Gut Microbiome. Cell. 2020;181:1661-79.

235. Fouhy F, Watkins C, Hill CJ, O'Shea CA, Nagle B, Dempsey EM, et al. Perinatal factors affect the gut microbiota up to four years after birth. Nat Commun. 2019;10:1517.

236. Johnson AJ, Vangay P, Al-Ghalith GA, Hillmann BM, Ward TL, Shields-Cutler RR, et al. Daily Sampling Reveals Personalized Diet-Microbiome Associations in Humans. Cell Host Microbe. 2019;25:789-802.e5.

237. Barton W, Penney NC, Cronin O, Garcia-Perez I, Molloy MG, Holmes E, et al. The microbiome of professional athletes differs from that of more sedentary subjects in composition and particularly at the functional metabolic level. Gut. 2018;67:625-33.

238. Pasolli E, Asnicar F, Manara S, Zolfo M, Karcher N, Armanini F, et al. Extensive Unexplored Human Microbiome Diversity Revealed by Over 150,000 Genomes from Metagenomes Spanning Age, Geography, and Lifestyle. Cell. 2019;176:649-662.e20.

239. Goodrich JK, Waters JL, Poole AC, Sutter JL, Koren O, Blekhman R, et al. Human genetics shape the gut microbiome. Cell. 2014;159:789-99.

\section{Publisher's Note}

Springer Nature remains neutral with regard to jurisdictional claims in published maps and institutional affiliations.

Ready to submit your research? Choose BMC and benefit from:

- fast, convenient online submission

- thorough peer review by experienced researchers in your field

- rapid publication on acceptance

- support for research data, including large and complex data types

- gold Open Access which fosters wider collaboration and increased citations

- maximum visibility for your research: over $100 \mathrm{M}$ website views per year

At BMC, research is always in progress.

Learn more biomedcentral.com/submissions 